III) Pohjoismaiden ministerineuvosto

Pohjoismaat ihmiskaupan markkinaalueena 



\section{Pohjoismaat ihmiskaupan markkina-alueena}

TemaNord 2018:514 


\section{Pohjoismaat ihmiskaupan markkina-alueena}

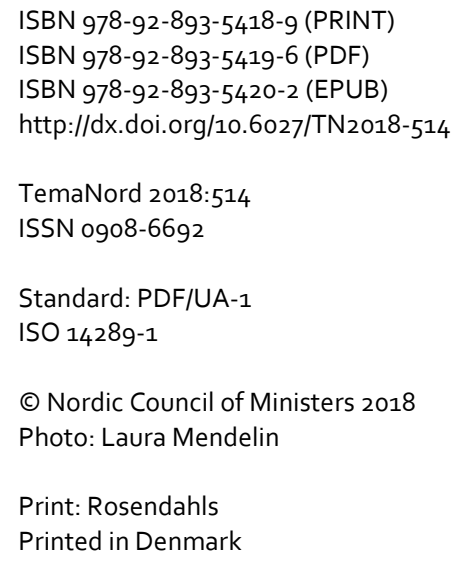

\section{Disclaimer}

This publication was funded by the Nordic Council of Ministers. However, the content does not necessarily reflect the Nordic Council of Ministers' views, opinions, attitudes or recommendations.

Rights and permissions

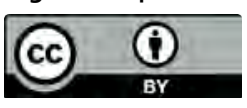

This work is made available under the Creative Commons Attribution 4.0 International license (CC BY 4.0) https://creativecommons.org/licenses/by/4.0.

Translations: If you translate this work, please include the following disclaimer: This translation was not produced by the Nordic Council of Ministers and should not be construed as official. The Nordic Council of Ministers cannot be held responsible for the translation or any errors in it.

Adaptations: If you adapt this work, please include the following disclaimer along with the attribution: This is an adaptation of an original work by the Nordic Council of Ministers. Responsibility for the views and opinions expressed in the adaptation rests solely with its author(s). The views and opinions in this adaptation have not been approved by the Nordic Council of Ministers.

Third-party content: The Nordic Council of Ministers does not necessarily own every single part of this work. The Nordic Council of Ministers cannot, therefore, guarantee that the reuse of third-party content does not infringe the copyright of the third party. If you wish to reuse any third-party content, you bear the risks associ- 
ated with any such rights violations. You are responsible for determining whether there is a need to obtain permission for the use of third-party content, and if so, for obtaining the relevant permission from the copyright holder. Examples of third-party content may include, but are not limited to, tables, figures or images.

\section{Photo rights (further permission required for reuse):}

Any queries regarding rights and licences should be addressed to:

Nordic Council of Ministers/Publication Unit

Ved Stranden 18

DK-1061 Copenhagen K

Denmark

Phone +4533960200

pub@norden.org

\section{Nordic co-operation}

Nordic co-operation is one of the world's most extensive forms of regional collaboration, involving Denmark, Finland, Iceland, Norway, Sweden, and the Faroe Islands, Greenland and Åland.

Nordic co-operation has firm traditions in politics, economics and culture and plays an important role in European and international forums. The Nordic community strives for a strong Nordic Region in a strong Europe.

Nordic co-operation promotes regional interests and values in a global world. The values shared by the Nordic countries help make the region one of the most innovative and competitive in the world.

\section{The Nordic Council of Ministers}

Nordens Hus

Ved Stranden 18

DK-1061 Copenhagen K, Denmark

Tel.: +453396 o200 www.norden.org

Download Nordic publications at www.norden.org/nordpub 



\section{Sisältö}

Yhteenveto .7

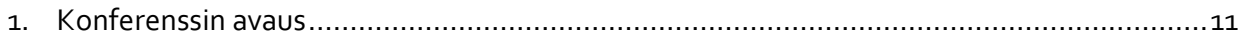

2. Aihe: Lapset ihmiskaupan uhreina …...............................................................

2.1 Ihmiskaupan uudet muodot Euroopassa......................................................15

2.2 Lapset, turvapaikanhakijat ja ihmiskauppa ......................................................18

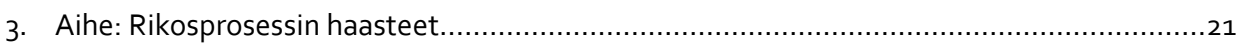

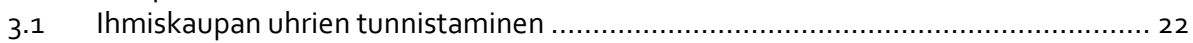

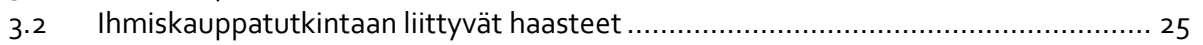

4. Aihe: Naiset ja miehet ihmiskaupan uhreina........................................................ 29

4.1 Hyväksikäytön psyykkiset seuraukset ja rikosprosessi .................................... 29

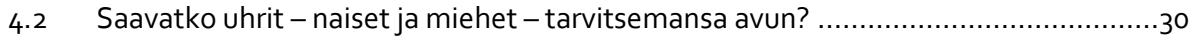

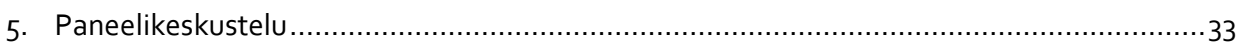

5.1 Miten Pohjoismaat voivat tehdä yhteistyötä ihmiskauppaa vastaan? ......................33

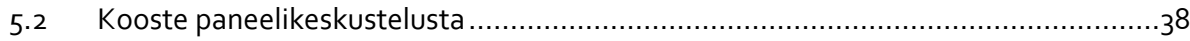

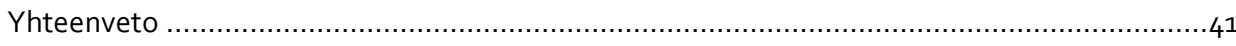

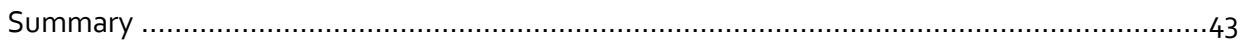





\section{Yhteenveto}

Pohjoismainen konferenssi Pohjoismaat ihmiskaupan markkina-alveena järjestettiin 26.10.2016 Helsingissä.

Konferenssissa keskusteltiin Pohjoismaiden yhteisistä haasteista ihmiskaupan torjunnassa. Tavoitteena oli vaihtaa kokemuksia ihmiskaupan uusista suuntauksista, lapsista ihmiskaupan uhreina, rikosprosessista uhrien tunnistamisesta tuomioistuimen päätöksiin sekä uhrien tunnistamisesta ja auttamisesta. Koko konferenssiohjelmaan oli sisällytetty tasa-arvo- ja sukupuolinäkökulma; kaikille puhujille oli annettu tehtäväksi pohtia esityksissään, miten ihmiskauppa vaikuttaa naisiin ja miehiin, tyttöihin ja poikiin.

Ihmiskaupan uusissa muodoissa käytetään tänä päivänä hyväksi naisia ja miehiä, tyttöjä ja poikia pakottamalla heidät rikolliseen toimintaan, työhön eri aloilla ja myymään seksipalveluja. Ihmiskauppiaat houkuttelevat näitä ihmisiä matkustamaan Pohjoismaihin Euroopan muista osista lupauksilla työstä ja asunnosta. Käyttämällä hyväkseen Pohjoismaiden hyvinvointijärjestelmää ihmiskauppiaat hankkivat myös uhrien identiteettejä käyttämällä väärin perustein muun muuassa sosiaalisia etuuksia. Uhrit eivät useimmiten ole tietoisia siitä, että heitä käytetään hyväksi rikollisessa toiminnassa.

Yksi ihmiskaupan torjunnan tämänhetkisistä haasteista Pohjoismaissa on se, että ihmiskauppiaat katsovat pohjoismaat yhdeksi markkina-alueeksi ja lähettävät uhreja maasta toiseen. Samat inmiskauppiaat toimivat samanaikaisesti eri Pohjoismaissa. Tämä muodostaa rikostutkijoille suuria haasteita, sillä lainsäädäntö on kansallista ja rikokset rajat ylittäviä. Tämä tarkoittaa, että viranomaisten ja järjestöjen välillä tarvitaan enemmän yhteistyötä ihmiskaupan vastaisten toimien ja rikostorjunnan tehostamiseksi.

Konferenssin lähtökohtana toimivat tulokset ja kokemukset, joita Pohjoismaiden ministerineuvosto ja Pohjoismaissa toimivat järjestöt ovat saaneet yhteispohjoismaisissa hankkeissa. Tänä päivänä Pohjoismaissa on paljon raportteja, analyyseja ja suosituksia toimenpiteistä ihmiskaupan torjumiseksi. Ne perustuvat kansallisten toimien yhteydessä saatuihin kokemuksiin.

Konferenssissa keskusteltiin kolmesta aihekokonaisuudesta, ja se päättyi paneelikeskusteluun:

- Lapset ihmiskaupan uhreina.

- Rikosprosessin haasteet.

- Naiset ja miehet ihmiskaupan uhreina.

- Paneelikeskustelu: Miten Pohjoismaat voivat tehdä yhteistyötä ihmiskauppaa vastaan?

Konferenssissa keskusteltiin seuraavanlaisista kysymyksenasetteluista: 
- Millaisia ihmiskaupan uusia muotoja Pohjoismaissa ja Euroopassa paljastuu?

- Mitä haasteita poliisi ja syyttäjät nykyään kohtaavat prosessissa, joka liittyy ihmiskaupan eri muotoja koskeviin tutkintoihin?

- Miten ihmiskaupan uhreiksi joutuneita lapsia käytetään hyväksi, ja miten tapauksia käsitellään?

- Miten naisia ja miehiä käytetään hyväksi ihmiskaupassa?

- Miksi seksuaalisessa hyväksikäytössä tapahtuva ihmiskauppa on tasaarvokysymys?

- Mitä menetelmiä tekijät käyttävät saadakseen uhrinsa valtaansa?

- Mitkä ovat ihmiskaupan psyykkiset seuraukset?

- Miten voidaan parhaiten vaihtaa kokemuksia, työmenetelmiä ja tietämystä?

- Miltä monialainen tutkimusyhteistyö voisi käytännössä näyttää?

- Mitä pohjoismaisella yhteistyöllä voidaan saada aikaan?

Konferenssiin kokoontui 160 osanottajaa kaikista Pohjoismaista. Heistä 37 oli poliiseja sekä 32 syyttäjiä, tuomareita ja asianajajia, eli yhteensä $43 \%$ edusti poliisi- ja oikeuslaitosta. Muut osanottajat olivat virkamiehiä, asiantuntijoita, tutkijoita ja kansalaisjärjestöjen edustajia.

Konferenssin järjesti Suomen yhdenvertaisuusvaltuutettu, joka toimii myös Suomen kansallisena ihmiskaupparaportoijana, yhteistyössä Suomen Pohjoismaiden ministerineuvoston puheenjohtajuuden kanssa. Konferenssin rahoitti Pohjoismaiden ministerineuvosto, ja rahoitukseen osallistuivat tasa-arvoasiain ja oikeusyhteistyön ministerineuvostot sekä Pohjoismainen lapsi- ja nuorisoyhteistyön komitea (NORDBUK).

Konferenssin Pohjoismaat ihmiskaupan markkina-alueena esityksiin voi tutustua seuraavan linkin kautta: https://www.syrjinta.fi/fi/web/fi/-/konferenssi-pohjoismaatihmiskaupan-markkina-alueena 


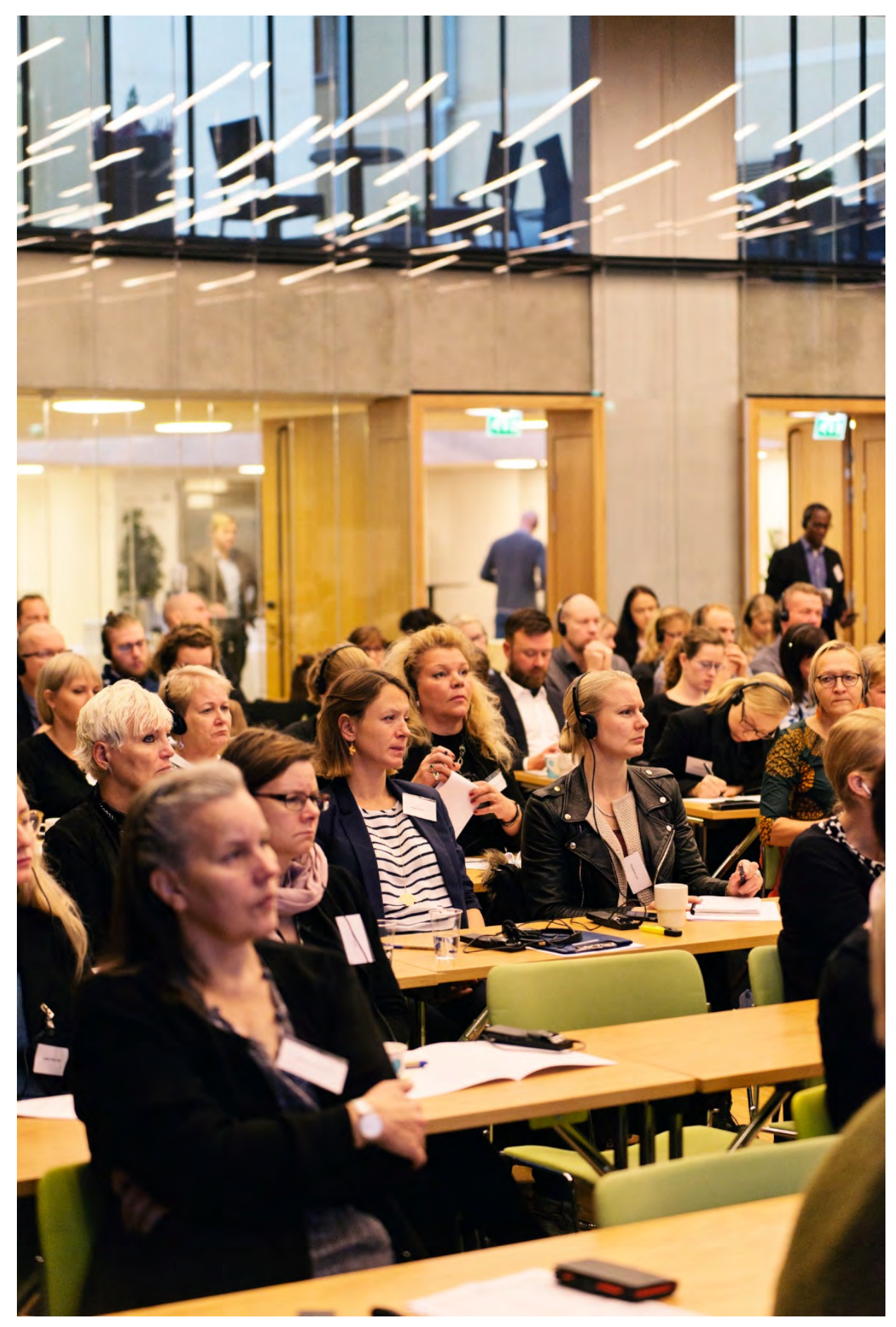





\section{Konferenssin avaus}

- Moderaattori: Venla Roth, ylitarkastaja, yhdenvertaisuusvaltuutetun toimisto, Suomi

Yhdenvertaisuusvaltuutettu Kirsi Pimiä, Suomen kansallinen ihmiskaupparaportoija, avasi konferenssin sanomalla, että konferenssi tarjoaa osanottajille foorumin ihmiskaupan torjunnassa kohdattaviin haasteisiin liittyvien kokemusten vaihtoon. Konferenssin on myös tarkoitus lisätä ymmärrystä ja tietoa ihmiskaupasta sekä saada aikaan ehdotuksia toimenpiteistä, joiden avulla voidaan ratkaista yhteisiä haasteita. Konferenssissa keskustellaan uusista haasteista, joita tällä hetkellä ei Pohjoismaissa tunnisteta riittävän hyvin. Kysymys on muun muassa ihmiskaupasta, jossa lapsia ja täysi-ikäisiä pakotetaan rikolliseen toimintaan.

\section{Kuva 1: Kirsi Pimiä}

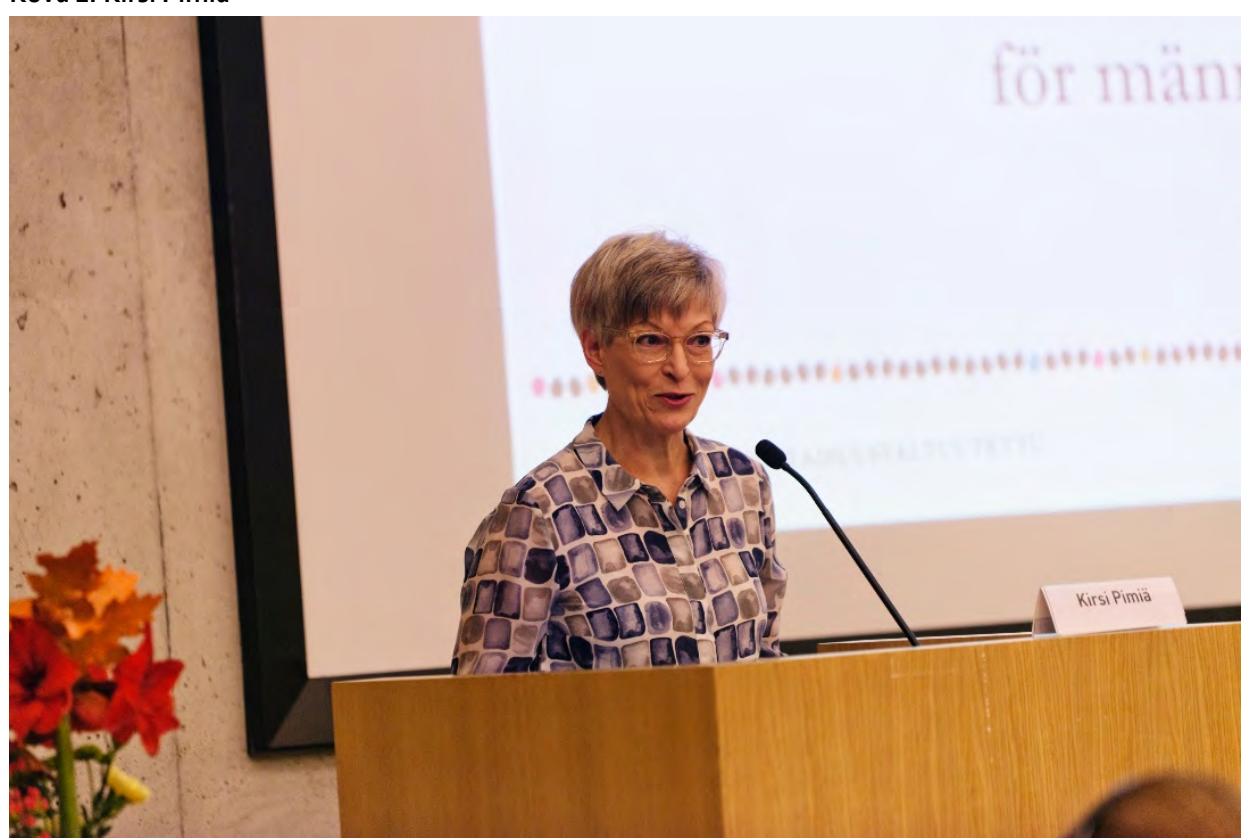

Suomen kansallinen ihmiskaupparaportoija on itsenäinen, riippumaton viranomainen, jonka tehtävänä on valvoa ja edistää ihmiskaupan vastaista toimintaa. Tämä tapahtuu keräämällä ja analysoimalla tietoa sekä raportoimalla ja tekemällä konkreettisia ehdotuksia lainsäädännön muuttamisesta ja menetelmistä, joiden avulla ihmiskauppaa voidaan paljastaa tehokkaammin.

Seitsemän vuotta sitten, kun kansallinen ihmiskaupparaportoija aloitti työnsä, ihmiskauppaa koskevia poliisitutkintoja tehtiin ja tuomioita oli annettu vain vähän. Vain 
pieni osuus uhreista sai apua ja järjestelmän oikeusturva oli heikko. Monista haasteista huolimatta on Suomi muiden Pohjoismaiden tavoin saanut näiden seitsemän vuoden aikana määrätietoisella työllä tuloksia niin ihmiskaupan uhrien paremmassa tunnistamisessa kuin rikosprosessien kehittämisessäkin.

On tärkeää keskustella siitä, miten ihmiskauppaa koskevia rikostutkintoja voitaisiin parantaa. Nykyään ymmärretään, että poliisin, auttamisjärjestelmän, kansalaisjärjestöjen ja sosiaali- ja työsuojeluviranomaisten välinen yhteistyö on edellytys onnistuneelle esitutkinnalle ja uhrien oikeuksien toteutumiselle. Seksuaaliseen hyväksikäyttöön liittyvissä ihmiskaupparikoksissa otetaan nykyään huomioon seksuaalisen hyväksikäytön seuraukset uhreille, kuten psyykkiset traumat, sekä se, että nämä seuraukset voivat johtaa muun muassa uhrin osallistumiseen itse rikosprosessiin. Suomessa rikosten esitutkinnan laatu vaihtelee sen mukaan, missä osassa maata se tehdään. Tämä johtuu siitä, ettei ihmiskauppaa tunnisteta tai osata tutkia. Pelkkä ihmiskaupan tunnistaminen ei riitä, vaan tarvitaan sekä resursseja että tietoa. Niissä maissa, joissa ihmiskaupan rajat ylittävää luonnetta painotetaan, poliisilaitoksen sisällä on perustettu erityisiä yksikköjä esitutkinnan tukemiseen, jottei yksittäisten poliisien tarvitse työskennellä yksin. Suomen kansallinen raportoija on ehdottanut, että Suomen poliisissa pitäisi pohtia ihmiskauppatapausten tutkimiseen erikoistuneen yksikön perustamista. Näin poliisilaitoksen sisälle saataisiin ryhmä, joka voisi tehokkaammin torjua ihmiskaupparikoksia. Kansallinen raportoija katsoo, että poliisin pitäisi myös laatia strategia ihmiskaupan torjunnalle ihmiskauppaan liittyvän esitutkintatyön tehostamiseksi. Mitä tulisi tehdä, jotta esitutkintaviranomaiset tunnistaisivat ihmiskauppaa paremmin, tuntisivat uhrien oikeudet ja pystyisivät luomaan luottamuksellisen ilmapiirin, jotta uhrit uskaltaisivat kertoa kokemuksistaan? Miten paljastaa ihmiskauppaa erityisesti nyt, kun paperittomien osuus tehtyjen lainmuutosten seurauksena oletettavasti tulee kasvamaan?

Kirsi Pimiä painotti, ettei ihmiskaupan vastainen toiminta voi perustua vain yksittäisten asiantuntijoiden työhön. Kestävien tulosten saamiseksi rakenteiden ja johdon on tuettava yksittäisten asiantuntijoiden työtä lainsäädännön, strategioiden ja suunnittelun osalta. Vuonna 2015 esiin on tullut erityisesti uusia ihmiskaupan muotoja, kuten valeavioliittoja (sham marriage) ja ihmiskaupan uhrien hyväksikäyttämistä rikollisessa toiminnassa, kuten varkauksissa ja huumausaineiden myynnissä. Tämä tarkoittaa, että ihmiskaupan parissa työskentelevät asiantuntijat tarvitsevat näitä uusia ilmiöitä koskevaa koulutusta voidakseen torjua ihmiskauppaa tehokkaasti.

Turvallisuus- ja pakolaiskriisit, nationalismin nousu, ihmisoikeuksien kyseenalaistaminen ja populistien esiinmarssi kuluneen vuoden aikana vaikuttavat myös ihmiskaupan vastaiseen toimintaan. Siksi on tärkeää työskennellä pitäen mielessä inmisoikeusnäkökulma, noudattaen kansainvälisiä sopimuksia ja pohjoismaiden tekemiä sitoumuksia sekä pitää niitä lähtökohtana ihmiskaupparikosten torjunnassa.

Ihmiskaupan uhrit elävät yhteiskunnan marginaalissa, eivätkä he ole vahvoja oikeuksiensa vaatijoita. Valtioiden tulee tehdä aktiivisesti työtä ihmiskaupan uhrien tunnistamiseksi, auttamiseksi ja suojelemiseksi. Pimiä päätti puheenvuoronsa seuraavasti: "Ihmisoikeudet kuuluvat kaikille siitä riippumatta, keitä me olemme ja 
mistä me tulemme. Ihmisoikeudet ovat demokraattisen oikeusvaltion peruskivi, jonka mureneminen ei ole kenenkään etu. Tasa-arvoinen yhteiskunta, joka kunnioittaa kaikkia, on mahdollinen ja loppujen lopuksi oma valintamme."

Sisäministeri Paula Risikon keskeinen viesti oli, että on luotava laajaa monialaista yhteistyötä, jotta ihmiskaupparikoksia voidaan tutkia ja ihmiskaupan uhreja tunnistaa ja auttaa tehokkaasti. Suomen hallitus esitteli lokakuussa 2016 ihmiskaupan vastaisia toimia koskevan uuden toimintasuunnitelman. Suomen toimintasuunnitelmassa käsitellään myös tämän seminaarin aiheita, kuten ihmiskaupan uhrien tunnistamiseen ja auttamiseen liittyvän työn tehostamista ja ihmiskaupan lapsinäkökulmaa. Ministeri Risikko totesi, että Suomen viranomaiset, kuten ministeriöiden koordinointiryhmä, kansallinen ihmiskaupparaportoija ja poliisi, uhrien auttamisjärjestelmä ja kansalaisjärjestöt tekevät esimerkillistä ja tehokasta yhteistyötä ihmiskaupan vastaisissa toimissaan ympäri Suomea. Pohjoismaihin on viime vuosina kohdistunut suuri pakolaisvirta. Tämä on saanut aikaan sen, että Suomessa ihmiskaupan uhrien kansallista auttamisjärjestelmää koordinoivan Joutsenon vastaanottokeskus on vastaanottanut aiempaa enemmän uhreja - uhrien lukumäärä on kaksinkertaistunut aiempiin vuosiin verrattuna. Auttamisjärjestelmän parissa työskentelevät asiantuntijat tekevät yhteistyötä muiden Pohjoismaiden kanssa ja erilaisten pohjoismaisten verkostojen puitteissa vaihtaakseen kokemuksia siitä, miten uhreja voidaan parhaiten auttaa sekä psyykkisesti että fyysisesti. Uhrien tunnistamisen lisääntyminen on myös tulosta ihmiskaupan vastaisista toimista ja määrätietoisesta työstä, ja se on johtanut siihen, että nykyään Suomessa tunnistetaan ihmiskaupan eri muotojen, ei ainoastaan pakkotyön, uhreja.

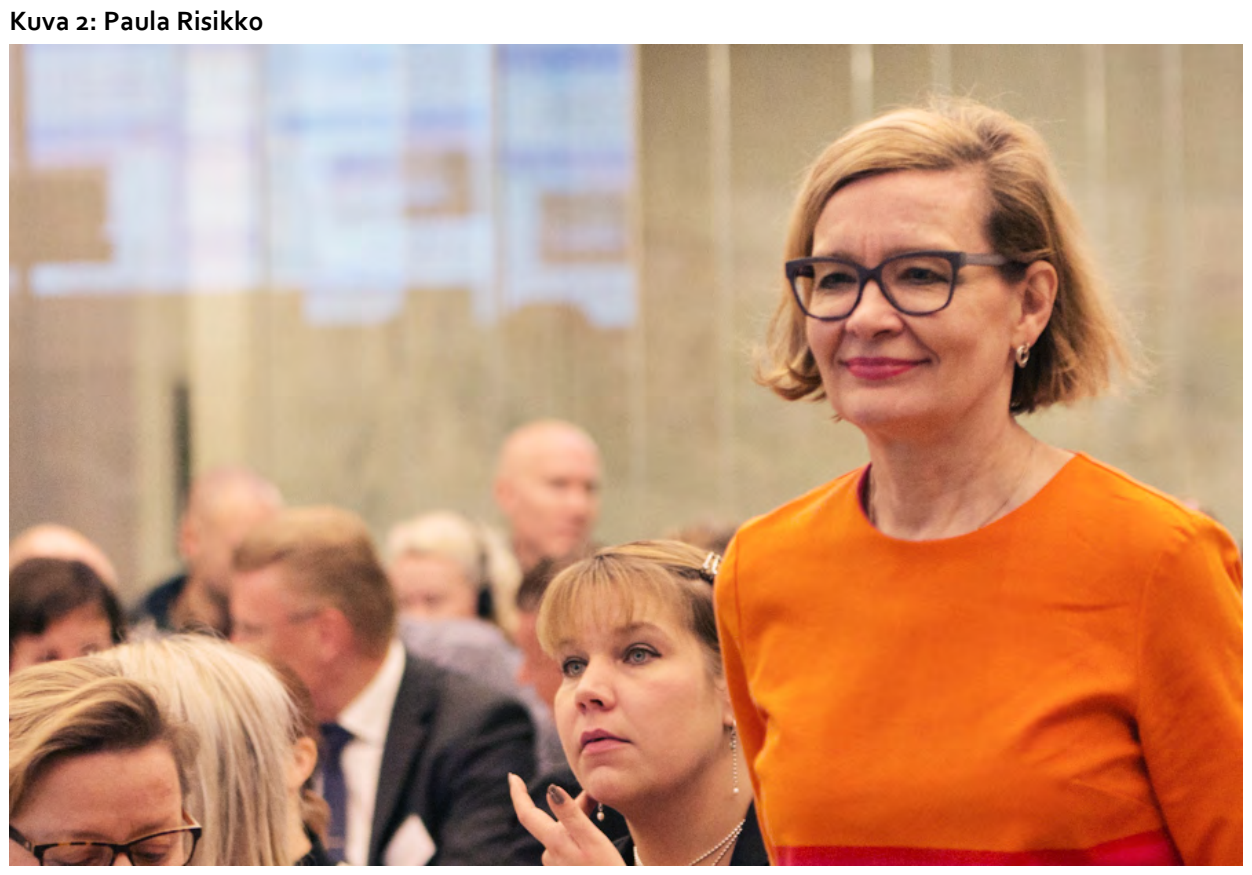


Ministeri Risikko painotti myös, että on tärkeää luoda tämän konferenssin kaltaisia foorumeita, joilla Pohjoismaiden asiantuntijat voivat yhdessä keskustella ja vaihtaa kokemuksia ihmiskaupan torjumisesta ja siitä, miten yhteisiä pohjoismaisia toimia voitaisiin parantaa ihmiskaupan vastaisen työn tehostamiseksi. Hän päätti puheenvuoronsa kiittämällä Suomen viranomaisia ja kansalaisjärjestöjä määrätietoisesta työstä, jota tehdään ruohonjuuritasolla - lähellä ihmisiä, jotka joutuvat ihmiskaupan uhreiksi. 


\section{Aihe: Lapset ihmiskaupan uhreina}

- Moderaattori: Terhi Tafari, tarkastaja, Ihmiskaupan uhrien auttamisjärjestelmä, Suomi

\subsection{Ihmiskaupan uudet muodot Euroopassa}

Syyttäjä Rudolf Christoffersen, Eurojust, Haag, Hollanti aloitti puheenvuoronsa toteamalla, ettei mikään maa voi olla ylpeä ihmiskaupan vastaisista toimistaan, koska Euroopassa annetaan tänä päivänä aivan liian vähän tuomioita ihmiskauppaan liittyvistä rikoksista.

Christoffersen kuvaili Euroopan nykyistä muuttunutta rikollisuuskuvaa ja sanoi sen johtuvan siitä, että itse rikollisuus ylittää valtioiden rajat, kun taas rikosten rangaistusjärjestelmät ovat kansallisia. Tämä johtaa siihen, että kansainvälisestä yhteistyöstä tulee yhä tärkeämpää. Yksi Pohjoismaiden ongelmista on se, että niiden hyvinvointijärjestelmiä sosiaaliavustuksineen on helppo käyttää hyväksi ja että ihmiskauppiaat näkevät Pohjoismaat yhtenä markkina-alueena ja siirtävät uhreja yhdestä Pohjoismaasta toiseen erilaista hyväksikäyttöä varten. Internet on muuttanut maailmaamme, ja siitä on tullut rikollisuuden näyttämö, johon liittyy kyberhyökkäyksiä, väärinkäyttöä, identiteettivarkauksia ja petosten eri muotoja. Tämä on tuonut poliiseille ja syyttäjille uusia haasteita. Rikokset tehdään yhdessä maassa, ja todisteet ovat toisessa maassa. Todisteaineisto on käännettävä kieleltä toiselle, mikä on kallista ja aikaavievää. Joskus rikosten muodot ovat toisenlaisia kuin mihin olemme tottuneet. Mailla on myös erilaiset prosessisäännöt todisteiden keräämistä varten, ja tämä tapahtuu sellaisten säännöstöjen ja prosessien mukaan, joita kaikki asianomaiset osapuolet eivät aina tunne.

Nykyään Euroopassa nähdään uusia ihmiskaupan muotoja. Rikolliset käyttävät hyväkseen lapsia ja haavoittuvassa asemassa olevia ihmisiä seksuaalista hyväksikäyttöä ja prostituutiota varten ja pakottavat heitä rikolliseen toimintaan, kuten myymälä- ja taskuvarkauksiin. Prostituutio ja seksuaalisen hyväksikäytön eri muodot ovat ihmiskaupan tavallisin muoto Euroopassa, joka koskee 69 \%:a kaikista tunnistetuista uhreista. Christoffersen kuvaili norjalaista tapausta, jossa 65 -vuotias mies Bergenistä osallistui lasten raiskaukseen Filippiineillä suoran verkkolähetyksen kautta. Europolin mukaan tämä rikollisuuden muoto on vakiintunut tosiasia. Ihmiset voivat istua omassa olohuoneessaan ja internetin kautta nähdä, miten lapsia käytetään seksuaalisesti hyväksi. He voivat myös vaikuttaa hyväksikäyttöön antamalla ohjeita siitä, miten lapsia käytetään hyväksi, omien seksuaalisten mieltymystensä mukaisesti. Ihmisten ei tarvitse enää matkustaa Aasiaan käyttääkseen lapsia seksuaalisesti hyväksi. Kyse on köyhistä lapsista, joita käytetään hyväksi muun muassa sieppausten avulla, 
mutta myös vanhemmat myyvät omia lapsiaan, koska voitto on niin suuri. Euroopassa on valitettavasti maita, joiden lainsäädännössä on aukkoja ja jotka eivät ole kieltäneet suoria verkkolähetyksiä. Norjalainen mies voidaan tuomita Norjassa, koska hän on suoran verkkolähetyksen kautta aktiivisesti osallistunut Filippiineillä tehtyyn raiskaukseen, kun taas hyväksikäytetty lapsi ei saa oikeusapua tai korvauksia. Internetin nopea kehittyminen on tuonut mukanaan sen, että ihmiskauppiaat käyttävät hyväkseen sosiaalista mediaa, kuten Facebookia, uhrien markkinoimiseen, rekrytoimiseen, myymiseen ja hyväksikäyttöön. Ihmiskauppa on siirtynyt kadulta digitaaliseen maailmaan. Etenkin lasten hyväksikäyttö verkossa on lisääntynyt voimakkaasti. Sekä ihmiskauppiaat että uhrit jättävät jälkiä, jotka voidaan tunnistaa, mutta tämä ei johda poliisin väliintuloon. Kaikista Hollannissa vuonna 2014 tunnistetuista uhreista $84 \%$ oli naisia, ja alaikäisten lasten osuus uhreista oli viidesosa. Nykyään jopa vastasyntyneitä lapsia myydään laittomasti Euroopan sisällä, esimerkiksi bulgarialaisia lapsia myydään Kyprokselle ja romanialaisia Englantiin.

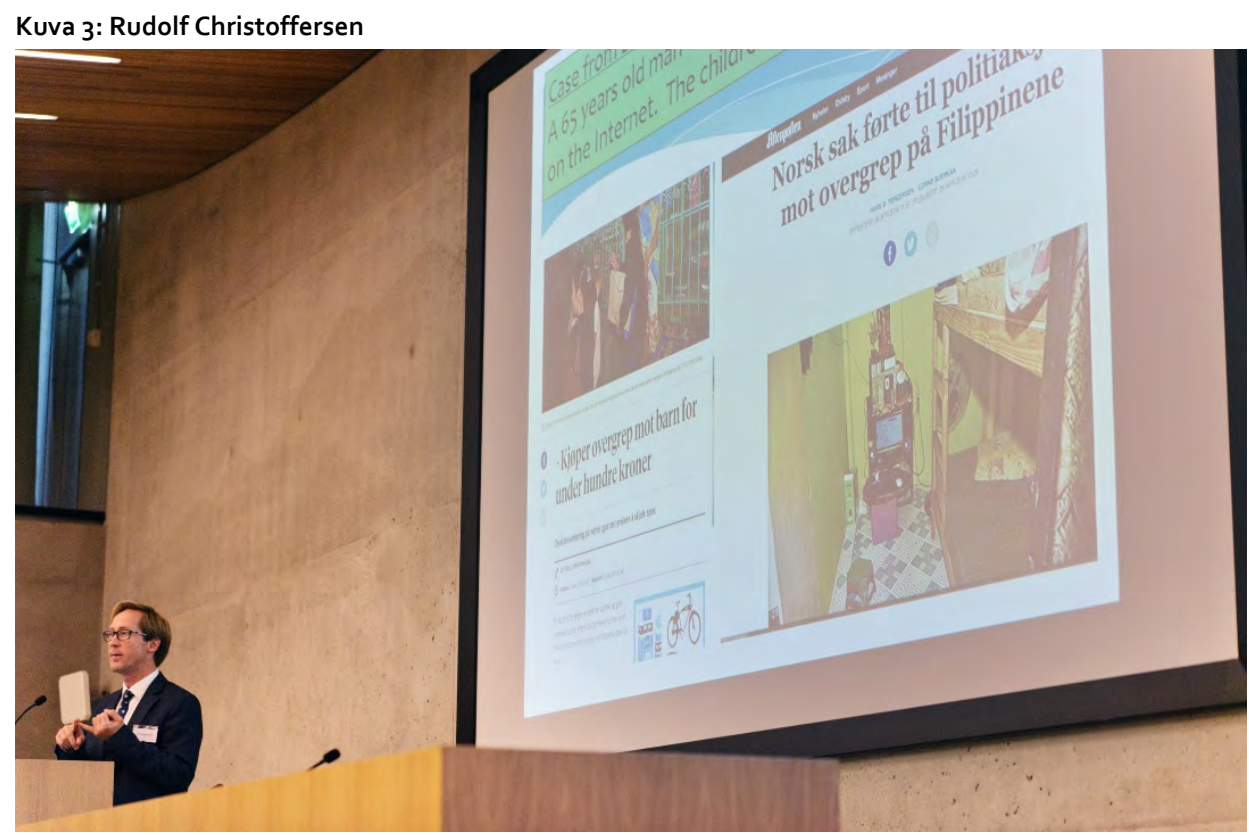

Tukipetokset, työmarkkinarikollisuus ja vilpillinen identiteettien käyttö liittyvät usein toisiinsa ja muodostavat suuren haasteen sekä poliisille että syyttäjille. Ihmiskauppiaat ottavat lainaa, ostavat tavaroita varastetuilla luottokorteilla ja nostavat väärennetyillä papereilla erilaisia sosiaaliavustuksia, jotka maksetaan ihmiskauppiaiden pankkitileille. Joskus he jopa nostavat sosiaaliavustuksia samaan aikaan useissa eri maissa. Työmarkkinarikollisuus perustuu nykyään siihen, että pieni palkka Pohjoismaissa on parempi kuin ei lainkaan tuloja omassa maassa. Tämä on useimmiten sekoitus laillista ja laitonta toimintaa. Christoffersen kertoi Norjan Bergenissä toimivasta siivousalan yrityksestä, joka rekrytoi hylätyn turvapaikkahakemuksen saaneita ihmisiä. Toiminta oli jatkunut yli 10 vuotta ennen kuin se paljastui. 
Eurojustin vuonna 2015 laatimassa raportissa Prosecuting THB for the purpose of labour exploitation kuvaillaan työvoimaa työmarkkinoilla hyväksi käyttämän inmiskaupan seitsemän indikaattoria. Niitä ovat esimerkiksi kielitaidon puute, takavarikoidut henkilöllisyystodistukset, laiton maahanmuutto ja velat. Yksi syistä tuomioiden vähäisyyteen on se, että hyväksikäytön tarkoitus on vaikea todistaa. Lue raportti:

- http://www.eurojust.europa.eu/press/PressReleases/Pages/2015/2015-12-14.aspx

- https://ec.europa.eu/anti-trafficking/sites/antitrafficking/files/report _on_prosecuting_thb_for_the_purpose_of_labour_exploitation_en_1.pdf

Lapsia käytetään hyväksi ja pakotetaan rikolliseen toimintaan, salakuljettamaan ja myymään huumeita ja tekemään taskuvarkauksia, ja nämä lapset tunnistetaan vain harvoin ihmiskaupan uhreiksi. Lapset voivat myös ensin olla ihmisten salakuljetuksen uhreja ja myöhemmin joutua ihmiskaupan uhreiksi. Pariisissa Ranskassa paljastui suuri tapaus, jossa bosnialaisia lapsia pakotettiin varastamaan julkisissa liikennevälineissä. Rikolliset ansaitsivat yli 2 miljoonaa euroa.

Miehet, jotka joutuvat ihmiskaupan uhreiksi, kokevat itsensä harvoin uhreiksi. He kokevat, ettei heillä ole ongelmia, he haluavat olla miehiä eivätkä haavoittuvia tai uhreja. Kun poliisi löytää heidät, he voivat esittää kysymyksen: mikä tämän maan poliisia vaivaa? He sanovat, että poliisin on pysyttävä erossa heidän ystävistään.

Christoffersen kertoi, että nuoria naisia Latviasta, Romaniasta, Puolasta, Tšekistä, Unkarista ja Slovakiasta rekrytoidaan pakkoavioliittoihin, jotka liittyvät inmiskauppaan. Näille nuorille naisille tarjotaan mahdollisuutta avioitua rahasummaa vastaan EU:n ulkopuolisista maista tulevien maahanmuuttajamiesten kanssa, jotta nämä miehet saavat oleskeluluvan EU:ssa. Juridinen haaste näiden rikosten tutkinnassa on se, että EUmailla on niin erilainen lainsäädäntö pakkoavioliittojen kohdalla. Hollanti on raportoinut syyrialaisten lapsimorsianten lukumäärän selvästä kasvusta pakolaiskriisin seurauksena. Yli 6o lapsimorsianta saapui Hollantiin syyskuun 2015 ja tammikuun 2016 välisenä aikana. Riskinä on, että näitä tyttöjä pidetään eristyksissä ja käytetään hyväksi taloudenhoitoapuna. Elinkauppa ei näy Pohjoismaissa, mikä johtuu siitä, että Pohjoismaiden hyvinvoinnin ja sairaanhoidon ansiosta ihmisillä ei ole niin suurta tarvetta ostaa elimiä. Elinkauppaa tapahtuu, ennen kuin pakolaiset tulevat Eurooppaan, kun uhrit myyvät elimiä rahoittaakseen pakolaismatkansa Eurooppaan. Esimerkiksi Libyalla ei ole elinkauppaa koskevia sääntöjä.

Christoffersen teki yhteenvedon vuonna 2016 nähdyistä suuntauksista:

- alaikäisten lasten hyväksikäytön lisääntyminen

- työmarkkinarikollisuuden lisääntyminen

- kyberrikollisuus, kuten alaikäisten tyttöjen ja poikien seksuaalinen hyväksikäyttö verkossa. 
Christoffersen sanoi, että koska ihmiskauppiaat kehittävät kaiken aikaa uusia menetelmiä naisten ja miesten ja tyttöjen ja poikien käyttämiseksi hyväksi eri tavoin, poliisissa ja syyttäjäkunnassa tarvitaan lisää osaamista ja erikoistumista. Kansalliset osaamisryhmät oikeuslaitoksen sisällä takaisivat, että ihmiskaupparikosten tutkinta asetetaan etusijalle ja että poliisilla ja syyttäjillä on tietoa ihmiskaupasta. Christoffersen päätti puheenvuoronsa seuraavasti: "Jos et tiedä, mitä etsiä, et myöskään näe sitä."

\subsection{Lapset, turvapaikanhakijat ja ihmiskauppa}

Yliopistonlehtori, oikeustieteen dosentti Märta Johansson Örebron yliopisto, Ruotsi aloitti kuvailemalla Ruotsissa kesällä 2015 julkaistua lapsikaupan kartoitusta ja sanoi, että raportti olisi näyttänyt erilaiselta, jos se olisi esitetty syksyn 2015 suuren pakolaisaallon jälkeen. Johansson kuvaili Ruotsin ihmiskauppaa koskevaa lainsäädäntöä (BrB 4:1a), joka perustuu Palermon pöytäkirjaan. Jos ihmiskauppa koskee tyttöjä ja poikia, syyttäjien ei tarvitse todistaa, että tiettyä keinoa, kuten pakottamista tai harhaanjohtamista, on käytetty. Lapsikaupan toteutumiseksi riittää, että on tehty kauppatoimenpide ja tarkoitus on hyväksikäyttö. Johansson esitteli tosiasiat, jotka kerättiin lapsista, joiden epäiltiin olevan ihmiskaupan uhreja. Kaikkiin Ruotsin kuntiin otettiin yhteyttä tietojen saamiseksi lapsista ihmiskaupan uhreina.

\section{Kuva 4: Märta Johansson}

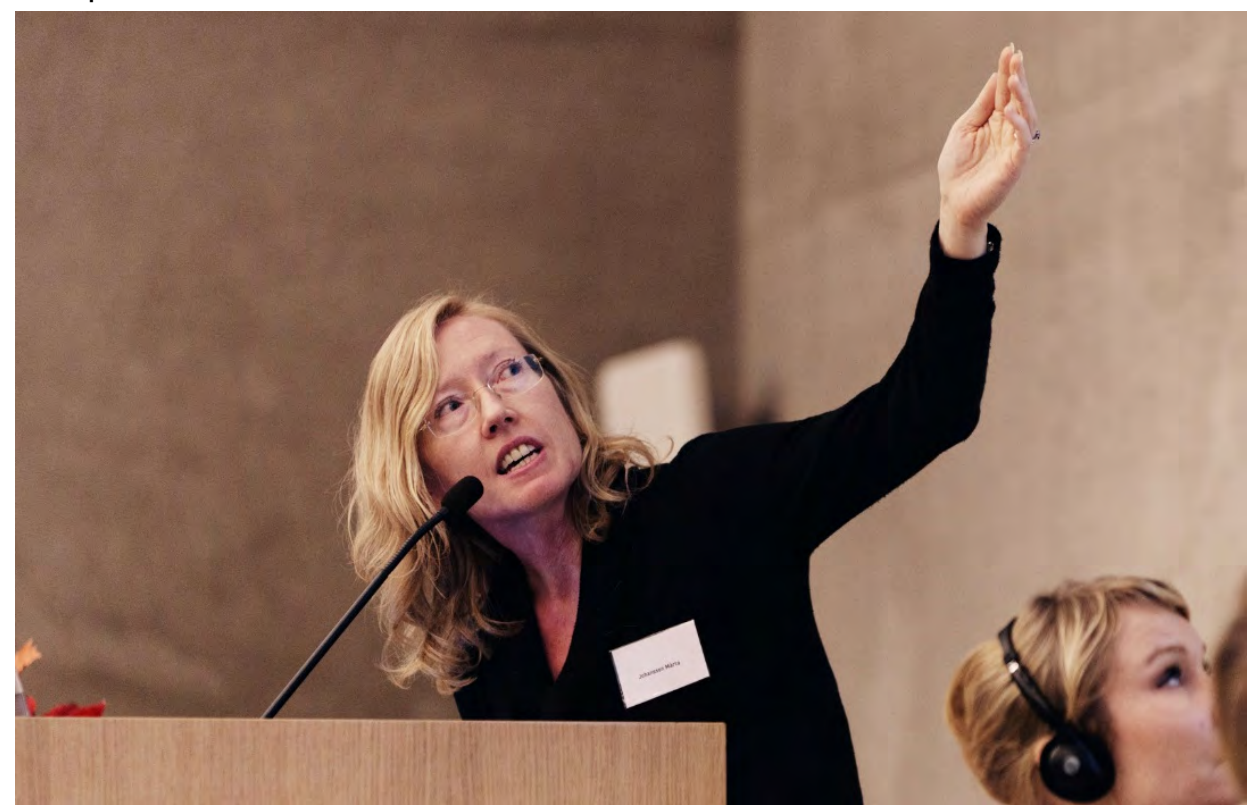

Viranomaiset ja järjestöt olivat tunnistaneet yhteensä 210 lasta, joista $54 \%$ oli tyttöjä / nuoria naisia ja $46 \%$ poikia / nuoria miehiä ja useimmat, $72 \%$ tytöistä, 15-17-vuotiaita. Useimmat lapset tulivat Afrikasta (44\%), suuri osa heistä Algeriasta ja Marokosta, ja muut ryhmät olivat muun muassa Aasiasta $(16,5 \%)$ ja Ruotsista $(8,5 \%)$. Useimmat olivat yksin maahan tulleita lapsia $(64 \%)$, ja näistä $54 \%$ oli turvapaikanhakijoita. Erityisen 
haavoittuvassa asemassa olivat yksin maahan tulleet turvapaikkaa hakevat lapset ja ne lapset, joilla oli velkaa matkasta. Muita ryhmiä olivat yksin maahan tulleet lapset, jotka eivät hae turvapaikkaa; lapset, jotka ovat EU:n kansalaisia ja jotka esimerkiksi saapuvat sellaisen aikuisen kanssa, joka ei ole lapsen huoltaja tai lapset, joiden huoltajat olivat ihmiskaupan uhreja. Seksuaalisessa hyväksikäytössä tapahtuva ihmiskauppa muodosti epältyjen hyväksikäytön muotojen suurimman ryhmän, yhteensä $41 \%$ (tytöistä $44 \%$ ja pojista $27 \%)$, ja muita olivat muun muassa pakkotyö, elinten poistaminen, sotapalvelus ja kerjääminen. Ryhmä lapsia, joiden epäiltiin joutuneen ihmiskaupan uhreiksi, olivat lapset, jotka katosivat ja tulivat takaisin, jotka eivät voineet hyvin palatessaan ja joilla oli mukanaan esimerkiksi erittäin kalliita vaatteita.

Johansson kuvaili haasteita, joita tulee vastaan, kun lasten epäillään joutuneen ihmiskaupan uhreiksi. Yhteensä 174 tapauksesta, joissa epäiltiin ihmiskauppaa Ruotsissa vuosina 2012-2015, ilmoitettiin poliisille $45 \%$, ja $47 \%$ :ssa tapauksista käynnistettiin poliisitutkinta mutta tutkinta ei johtanut yhteenkään syytteeseen. Lapsen kertomukset olivat taustalla $48 \%$ :ssa rikosilmoituksista. Johansson esitti kysymyksen: mitä ovat "riittävät epäilykset"? Kartoituksen mukaan epäilyksiä heräsi seuraavien seikkojen perusteella: lasten omat kertomukset sosiaalipalvelujen ja maahanmuuttoviraston edustajille, lapsen matkaan Ruotsiin liittyvät olosuhteet, lapsen katoaminen, yhteydet ja aikuiset lapsen ympärillä ja/tai tiettyjen tavaroiden, kuten kalliiden vaatteiden, tietokoneiden tms. saaminen. Johansson painotti, että riskialttiit lapset kertovat tarinansa erittäin varovaisesti ja antavat vain vähän yksityiskohtia hyväksikäyttö- ja ihmiskauppaepäilyistä.

Johansson päätti esityksensä kuvailemalla, mitä toimenpiteitä tulevaisuudessa tarvittaisiin lapsikaupan torjumiseen liittyvän työn tukemiseksi. Johansson sanoi, että Ruotsissa pitäisi olla keskitetty yhteyspiste, johon epäillystä lapsikaupasta voisi ilmoittaa. Viranomaisten pitäisi automaattisesti ilmoittaa epäilyksistään poliisille, ja poliisin ja syyttäjien pitäisi saada tietoa ja resursseja tutkiakseen rikosilmoituksia, jotka eivät ole seurausta etsintätoimista. Esitutkinnan johtajien pitäisi käyttää paremmin hyväkseen harkinta-aikaa ja antaa lapsille turvallinen sijoituspaikka. Vuosina 20122015 vain $22 \%$ :lle lapsista annettiin turvallinen sijoituspaikka poliisitutkinnan aikana.

Lääninkoordinaattori Lisa Green, Ihmiskaupan vastainen työ, Malmö, Ruotsi esitteli pakolaislasten kanssa tehtyä konkreettista työtä syksyllä 2015, kun suuria pakolaisryhmiä saapui Malmöhön. Kaikki kaupungin sosiaalityöntekijät sijoitettiin työhön, jonka tarkoitus oli rekisteröidä pakolaiset ja löytää heille asuinpaikka. 100 lisähenkilöä palkattiin työhön Malmöhön tulleiden pakolaisten kanssa. Kaikki henkilöt työskentelivät suuren paineen alaisina, ja vain lyhyesti pakolaisia ja lapsia haastateltuaan oli heidän pakko päättää, missä lapsen tuli asua. Uusia majoituspaikkoja avattiin joka päivä, urheiluhallit täyttyivät pakolaisista ja IKEAn kaikki patja- ja vuodevaatevarastot tyhjenivät. Yhden yön aikana saapui 300 lasta, ja silloin vastuu lasten sijoittamisesta oli 3-4:llä yövuorossa työskennelleellä sosiaalityöntekijällä. He saattoivat myös saada tiedon, että 10 minuutin kuluttua tulee 150 lasta. Green kuvaili millaista oli lyhyessä ajassa ottaa kantaa siihen, millainen suhde lapsella on aikuiseen henkilöön, jonka kanssa lapsi matkustaa, ja onko olemassa riski siitä, että lapsi voi olla ihmiskaupan uhri. Lapsia erotettiin omaisista. Sosiaalityöntekijöiden oli otettava 
kantaa siihen, sijoitettaisiinko tytöt/nuoret naiset laitosmajoitukseen vai omaan majoitukseen. Oli tärkeää kertoa pakolaisille, mitä oikeuksia Ruotsin laki antaa pakolaisille, sekä antaa heille tietoja lasten oikeuksista ja kertoa, ettei heidän ole pakko asua yhdessä isoveljen kanssa, jos tämä lyö heitä.

\section{Kuva 5: Lisa Green}

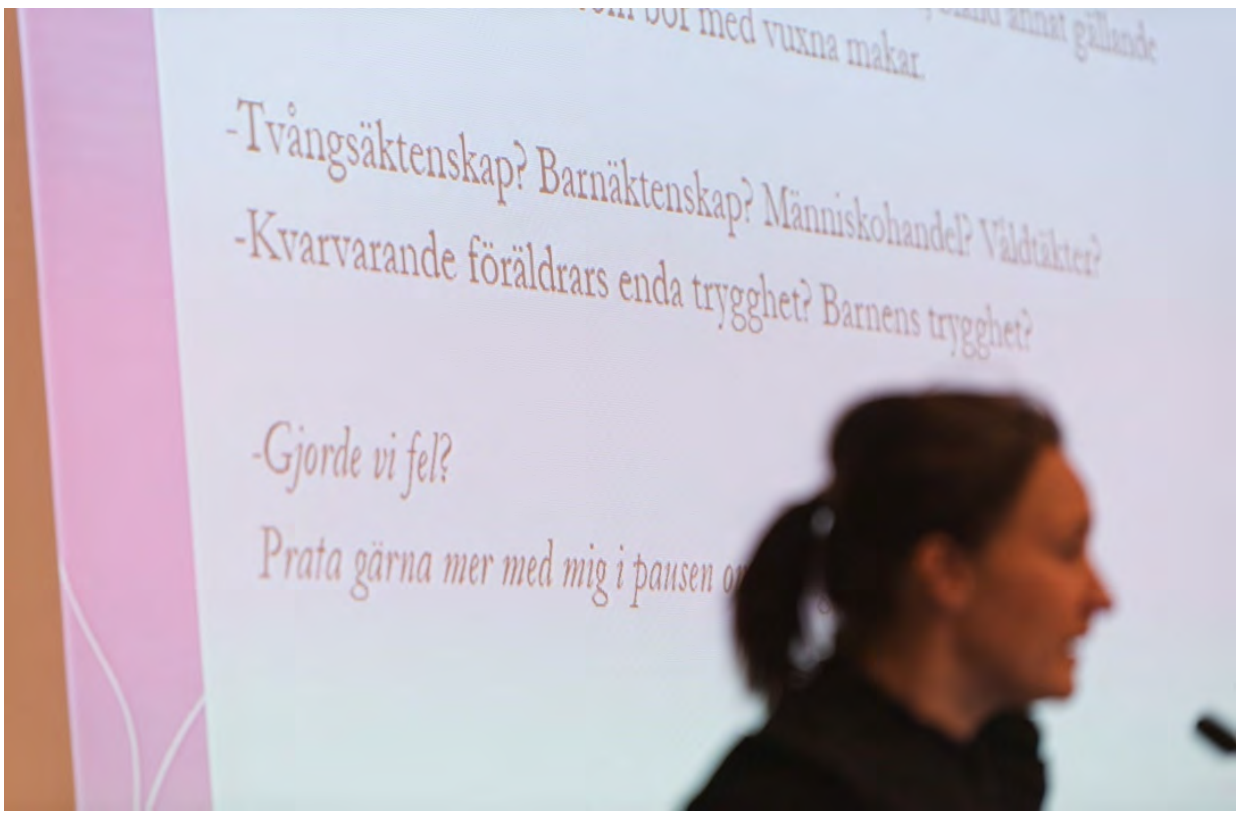

Lisa Green sanoi, että ihmiskaupan vastaisen työn lääninkoordinaattorina hänellä on paljon tietoa siitä riskistä, että saapuneet tytöt ja pojat voivat olla ihmiskaupan uhreja. Usein on vaikeaa todistaa, että tapauksessa on kyse ihmiskaupasta. Sosiaalityöntekijät arvioivat suojelun tarpeen luettelon pohjalta. Luettelo sisältää kysymyksiä, joihin tulee vastata, ja toimenpiteitä, jotka on toteutettava, ennen kuin lapsi ja aikuinen voidaan lähettää eteenpäin majoituspaikkaan. Tärkein kysymys Malmössä tehdyssä työssä oli, että Ruotsiin saapuneille pakolaislapsille oli luotava turvalliset olosuhteet. 


\section{Aihe: Rikosprosessin haasteet}

- Moderaattori: Helle Just Krag, pääsyyttäjä, Kööpenhaminan poliisi, Tanska

Pääsyyttäjä Helle Just Krag esitteli lyhyesti Operation Hvepsebon, jota on kutsuttu Tanskan tähän asti suurimmaksi ihmiskauppaan ja talousrikollisuuteen liittyväksi tapaukseksi. Köyhiä romanialaisia houkuteltiin Tanskaan vilpillisillä lupauksilla työstä, ja heidän identiteettiään käytettiin huijauksissa samaan aikaan, kun heidät pakotettiin asumaan kurjissa oloissa. Tanskan poliisi on yhteisessä tutkinnassa tehnyt virallista yhteistyötä Romanian kanssa tapauksen tutkimiseksi.

Kuva 6: Helle Just Krag

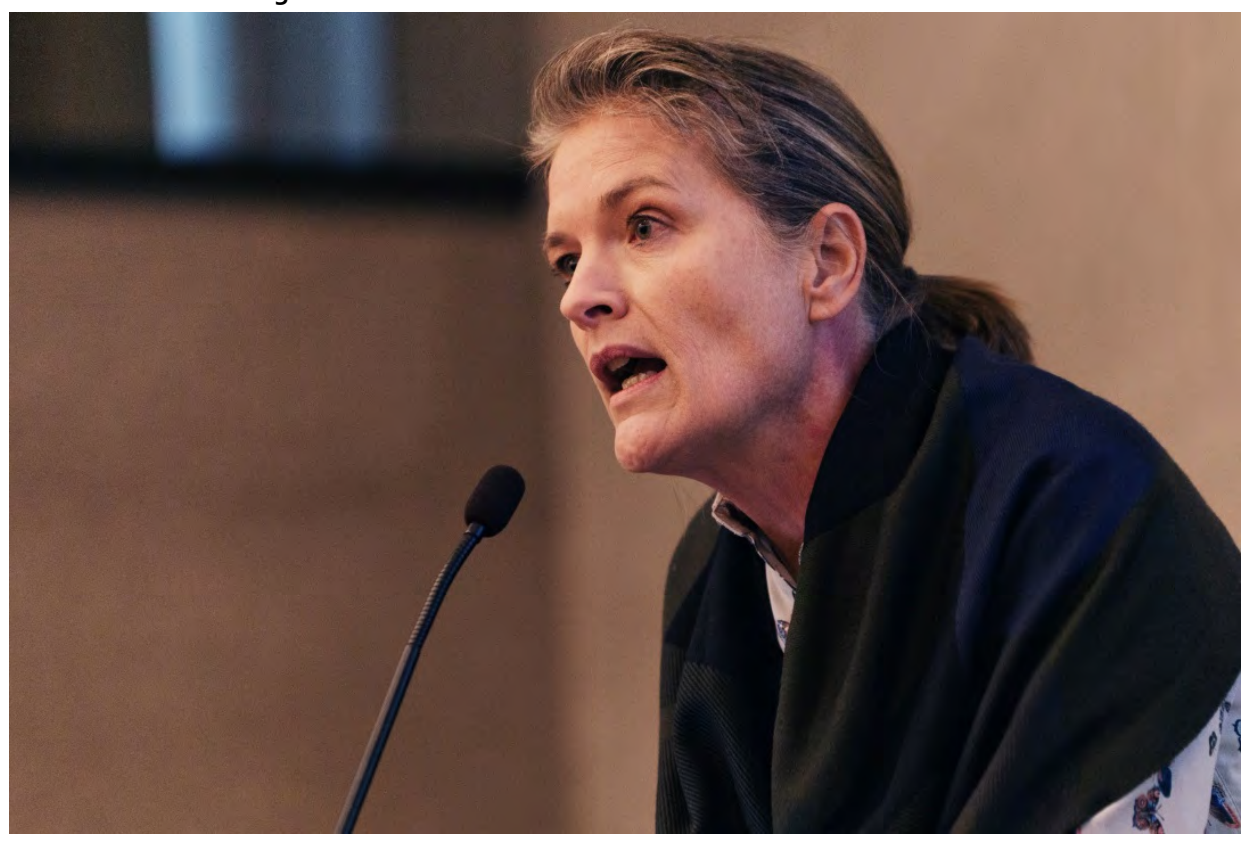

Operation Hvepsebo on erityinen, koska epäillyt uhrit puhtaasti juridisesti nähtynä ovat syyllistyneet petokseen, koska rikokset on tehty heidän nimissään. Kyseessä on ensimmäinen kerta, kun tanskalainen syyttäjäviranomainen on yrittänyt saada syytetyt tuomituiksi syyttömien ihmisten identiteettien hyväksikäytöstä ihmiskaupassa ja petoksissa.

Tapauksessa Operation Hvepsebo syyttäjät ovat nostaneet syytteitä ihmiskaupasta, törkeistä petoksista ja puhelimen käytöstä vankilassa, ja tapaus on jaettu kolmeen oikeudenkäyntiin. Tähän mennessä on tuomittu 40 henkilön kohdalla yhteensä 19 henkilöä ihmiskaupasta ja yhteensä 31 miljoonan Tanskan kruunun (noin 4,13 miljoonan euron) arvoisesta petoksesta. 


\subsection{Ihmiskaupan uhrien tunnistaminen}

Anders Morville, rikostutkija, Task Force Indbrud, Pohjois-Själlandin poliisi, Tanska aloitti esityksensä kertomalla, miten Tanskan poliisi vuonna 2014 huomasi tapauksen murtoja ja varkauksia koskeneen tutkinnan yhteydessä. Poliisi epäili arabialaistaustaisen miehen olevan rikollisryhmän johtaja ja majoittaja ja myyvän varastettua tavaraa ja käynnisti miehen puhelinkuuntelun. Poliisi sai Tanskan muilta poliisialueilta tietoja romanialaisista, jotka tekivät samankaltaisia petoksia. Arabialainen asunnonomistaja otettiin kuulusteltavaksi, ja hän kertoi, että asunto on vuokrattu romanialaiselle henkilölle. Poliisi alkoi kesäkuun 2014 lopulla salakuunnella romanialaista, jonka oletettiin olevan varkauksien takana. Salakuunteluprosessissa kävi selväksi, ettei kyse ollut murroista ja varkauksista vaan ihmiskaupasta, jossa uhreja käytetään hyväksi talousrikollisuudessa. Tapaus osoittautui paljon suuremmaksi kuin mitä poliisi aluksi oletti.

\section{Kuva 7: Anders Morville}

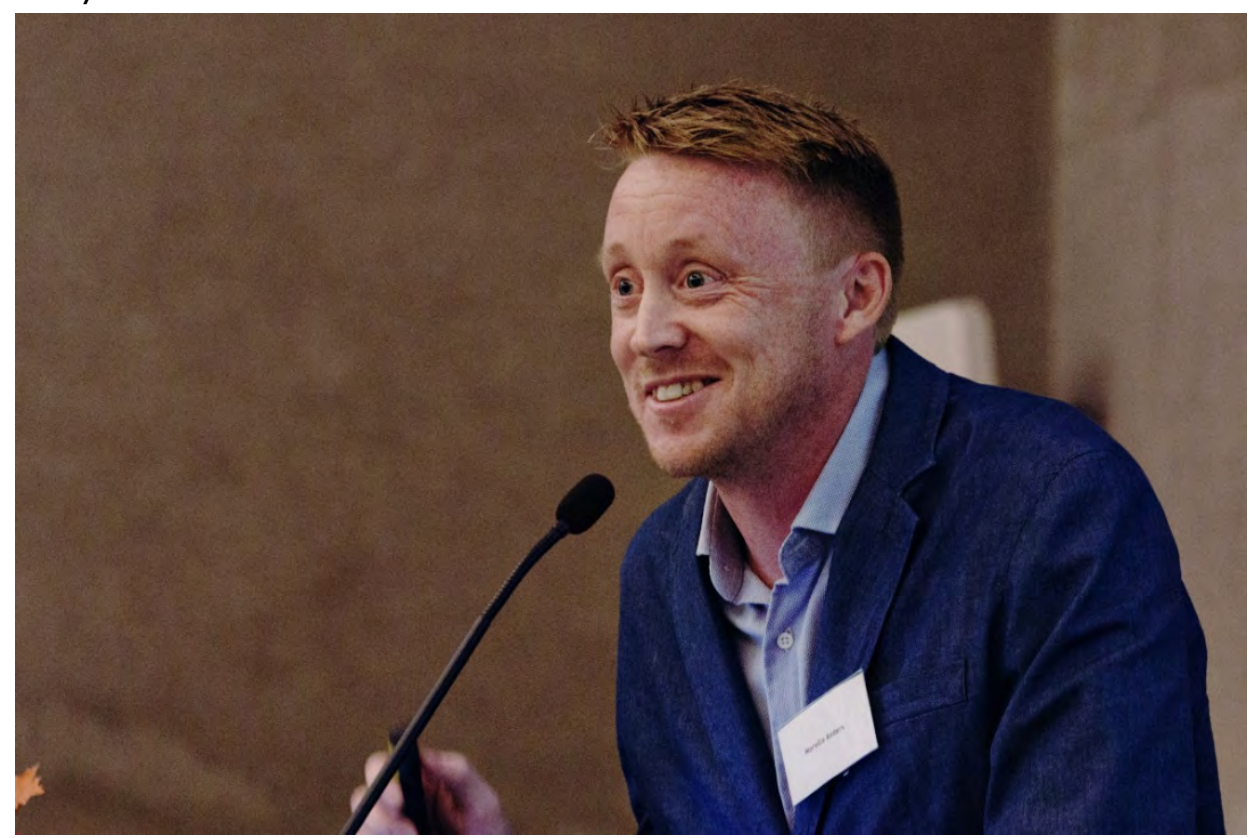

Poliisi teki ratsian 25. helmikuuta 2015, tutki 62 osoitetta ja otti kiinni 95 henkilöä. Kiinni otetut jaettiin useaan soluun. Poliisi seurasi kolmea solua kartoittaakseen menettelytavan, rekrytointi-, kuljetus- ja majoitustavan ja sen, miten henkilöt rekisteröitiin muun muassa kansalaispalveluihin ja Tanskan veroviranomaisen kirjoihin. Oletetut uhrit kertoivat, ettei heitä oltu uhattu eikä muulla tavoin pakotettu matkustamaan Tanskaan. Petos toimi yleensä siten, että romanialaisten maanmies etsi heidät käsiinsä ja houkutteli heidät Tanskaan lupaamalla töitä ja vastineeksi palkan, kuljetuksen, ruoan ja majoituksen. Ihmiskauppiaat rekrytoivat vähemmän varakkaita henkilöitä, joiden piti olla yli 30-vuotiaita miehiä ja lukutaidottomia ja jotka eivät osanneet puhua eivätkä ymmärtäneet englantia. Saapuessaan heidät majoitettiin eri 
osoitteisiin Tanskassa. Saatuaan tanskalaisen CPR-numeron (henkilötunnuksen), sairausvakuutustodistuksen, NemKonton (Tanskan veroviranomaisen hyväksymän pankkitilin) ja tunnuslukulistan pankkitilin sähköistä käyttöä varten romanialaiset sijoitettiin taloon odottamaan työtä. Romanialaiset eivät koskaan asuneet niissä osoitteissa, jotka olivat ilmoittaneet rekisteröityessään kansalaispalveluun. Ihmiskauppiaat tunsivat hyvin Tanskan sosiaali- ja verojärjestelmän ja tekivät yhteistyötä tanskalaisen tilintarkastajan ja asianajajan kanssa.

Tämän jälkeen ihmiskauppiaat käyttivät näitä asiakirjoja ottaakseen pikalainoja, vuokratakseen autoja ja ostaakseen matkapuhelimia ja muita tavaroita internetistä. Lisäksi he olivat käyttäneet uhrien identiteettejä laajoihin veropetoksiin. Rikollinen ihmiskauppaverkosto perusti yrityksiä, jotka ovat olleet olemassa vain paperilla ja joihin he sijoittivat uhrit johtajiksi ja työntekijöiksi. Ihmiskauppiaat maksoivat kuvitteellisia palkkoja, joiden veroprosentti oli korkea, tehdäkseen veropetoksia, ja saivat palautuksia liian suurista ennakkoveroista uhrien pankkitileille.

Jette Malberg vanhempi syyttäjä, Task Force Indbrud, Pohjois-Själlandin poliisi, Tanska, joka nykyään toimii vanhempana syyttäjänä valtakunnansyyttäjänvirastossa Kööpenhaminassa, oli Operation Hvepsebon johtava syyttäjä. Jette Malberg kertoi, että ensimmäisinä kuukausina hän toimi ainoana syyttäjänä ja tutkintaan sijoitettiin yhteensä 30 rikostutkijaa, ja lopuksi tutkinnassa ja syytteen parissa työskenteli yhteensä neljä syyttäjää. Kaikkia henkilöitä, jotka poliisi oli löytänyt 62 osoitteesta, kuulusteltiin. 22 henkilöä pidätettiin ja heitä oli tarkoitus syyttää oikeudessa ihmiskaupasta ja törkeästä petoksesta. Oikeus päätti kuitenkin pidättää henkilöt ainoastaan törkeästä petoksesta.

\section{Kuva 8: Jette Malberg}

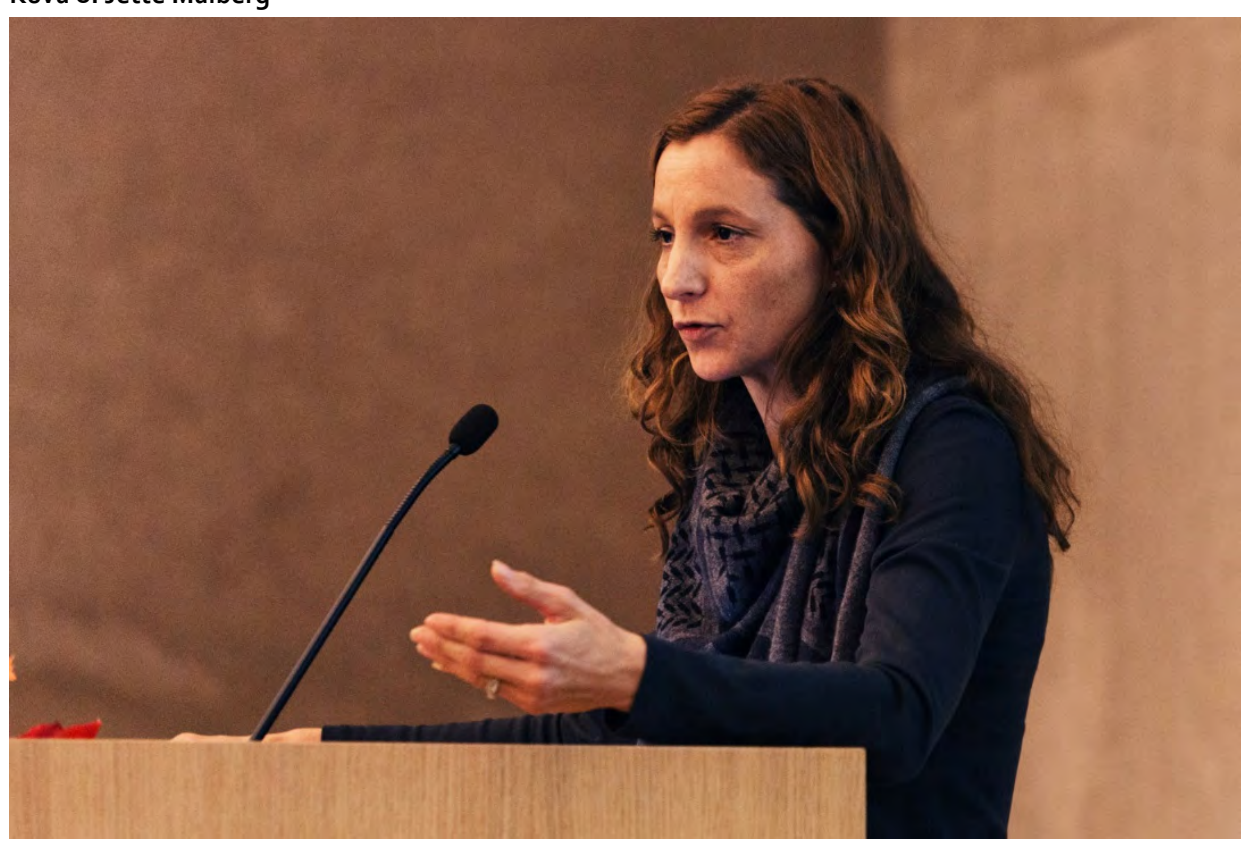


Jette Malberg kertoi, että valtionsyyttäjän (valtakunnansyyttäjän) kanssa pohdittiin tarkkaan, pitäisikö tapaus viedä oikeuteen petoksena vai ihmiskauppana ja mistä rikollisia pitäisi syyttää. Pakottaminen, jota inmiskauppatapauksissa edellytetään, ei myöskään ollut tyypillinen sopimaton keino, koska uhreja ei ollut pakotettu eikä uhattu, eikä heidän vapauttaan ollut riistetty. Tanskassa ei ole ennen ollut tapauksia, joissa uhrit olisivat olleet petoksen kohteena. Toinen harkittava asia oli tuomiovalta, eli missä oikeudessa tapausta pitäisi käsitellä ja mikä oli varsinainen rikospaikka. Tässä tapauksessa se oli vaikeaa määrittää, koska mahdollisia paikkoja oli useampi: paikka jossa henkilöt rekrytoitiin, johon heidät sijoitettiin Tanskassa asumaan tai paikka, jossa rikokset oli tehty. Tässä tapauksessa se oli internet, missä uhrien identiteettejä oli käytetty hyväksi. Päätöksenä oli syyttää tekijöitä ihmiskaupasta, ja tulos oli, että tapaus jaettiin kolmeen soluun ja sijoitettiin kolmeen eri tuomioistuimeen. Yhteensä kyse oli 1000:sta petostapauksesta. Koko tutkinta oli erittäin laaja ja vaati paljon resursseja:

- Solu 1 oli suurin tapaus ja koostui päämiehestä ja 13 avustajasta.

- Solu 2 koostui kahdesta vähemmän organisoidusta solusta, ja viisi henkilöä sai syytteen.

- Solu 3 koostui saman perheen sisaruksista, ja kolme henkilöä sai syytteen.

Haastavinta tapauksessa oli se, että todisteaineisto oli ennenkuulumattoman suuri. Yhteensä telekuunteluaineistolistauksia (tekstiviestejä, puhelinkeskusteluja, ei vastaanotettuja puheluja) oli 100000 , joista yli 10000 :ta keskustelua käytettiin tutkinnassa. Malberg painotti, että suurin ongelma oli valita, mitä esitettäisiin oikeudessa. Todisteita ei saanut olla liikaa eikä liian vähän.

Myös todistajat muodostivat haasteen. "Petosvyyhden" oli läpikäynyt 300400 henkilöä, jotka olivat saaneet henkilöllisyyspaperit ja joita rikolliset olivat käyttäneet hyväkseen. Tapauksessa 200 henkilön identiteettejä käytettiin hyväksi eri petoksissa. Syyttäjälaitos päätti nostaa syytteen ihmiskaupasta yhteensä 70 henkilön hyväksikäytön osalta. Oikeus katsoi, että 40 henkilöä, jotka olivat antaneet todistajanlausunnon, oli joutunut ihmiskaupan uhriksi, ja heitä odotettiin voitavan kuulustella oikeudenkäynnin aikana. Kaikissa kolmessa tapauksessa nostettiin syytteitä ihmiskaupasta, ja samaan aikaan nostettiin syytteitä myös petoksista, törkeästä verovilpistä ja matkapuhelinten käytöstä vankilassa.

$\mathrm{Ne}$ henkilöt, joita syytettiin solun 3 tapauksessa, tuomittiin kolmen henkilön ihmiskaupasta ja yhteensä 900000 Tanskan kruunun (n. 120000 euron) arvoisesta törkeästä petoksesta. Oikeus hylkäsi syytteet 15 henkilön hyväksikäytöstä inmiskaupassa. Oikeus pani painoa sille, että kaikki uhrit tulivat samasta pienestä kylästä. Perustelu oli, ettei kyseessä voinut olla harhaanjohtaminen, koska Tanskasta palanneet henkilöt olivat kertoneet, etteivät he olleet saaneet työtä niin kuin oli luvattu. Tuomio oli 2-3 vuotta vankeutta, ja kaikki tuomittiin karkotettaviksi Tanskasta. Tuomiosta valitettiin, ja tapausta on käsitelty Tanskan Landsrettenissä (hovioikeus) ja Højesteretissä (korkein oikeus). Tuomioita kovennettiin 3 ja 3,5 vuoden vankeudeksi. 
Solun 1 tapauksessa syytettiin 13:a henkilöä, ja 19 henkilön kohdalla 12 romanialaista tuomittiin ihmiskaupasta. Oikeus katsoi, että kyseessä oli 16 henkilön harhaanjohtaminen ja että kaikkiin henkilöihin oli kohdistettu sopimattomia keinoja. Ihmiskauppiaat tuomittiin 10,4 miljoonan Tanskan kruunun (n. 1,38 miljoonan euron) arvoisesta törkeästä petoksesta ja verovilpistä vankeuteen 7 vuoden ja 11 kuukauden sekä 3 vuoden välillä. Tanskalaiset vapautettiin ihmiskaupparikoksia koskevista syytteistä. Kolme henkilöä valitti tuomiosta Tanskan Landsretteniin (hovioikeus), ja Landsrettenin tuomio kahden ihmiskaupasta tuomitun henkilön osalta pysyi samana kuin Byrettenissä (käräjäoikeus). Henkilö, joka vapautettiin syytteistä Byrettenissä, vapautettiin ihmiskauppaa koskevista syytteistä myös Landsrettenissä, ja hänen rangaistuksensa lieveni 5 vuodeksi ja 6 kuukaudeksi.

Solun 2 tapauksessa syytettiin viittä henkilöä (kolmea Romanian ja kahta Syyrian kansalaista). Neljä tuomittiin ihmiskaupasta 18 henkilön kohdalla. Kaikki tuomittiin 4,8 miljoonan Tanskan kruunun (n. 640000 euron) arvoisesta petoksesta. Yksi henkilö tuomittiin 16,4 miljoonan Tanskan kruunun (n. 2,18 miljoonan euron) arvoisesta törkeästä verovilpistä. Rangaistus oli 3-7vuotta vankeutta, ja kaikki karkotettiin Tanskasta. Tapauksesta on valitettu Tanskan Landsretteniin (hovioikeus).

Yhteensä 19 henkilöä on tuomittu ihmiskaupasta 40 henkilön kohdalla ja yhteensä 31 miljoonan Tanskan kruunun (noin 4,13 miljoonan euron) arvoisesta petoksesta. Useimmat uhrit ovat miehiä (116), ja 15:tä naista käytettiin hyväksi. Kaikissa kolmessa tapauksessa mukana oli myös naisia, jotka syyllistyivät rikolliseen toimintaan. Oikeudenkäyntiaineisto koostui yhteensä 6500 sivusta, ja tuomio oli yhteensä 178 sivua pitkä.

\subsection{Ihmiskauppatutkintaan liittyvät haasteet}

Olafur Kjartansson, poliisipäällikkö, Suðurnesin poliisipiiri, Islanti, loi katsauksen ihmiskauppaan Islannissa ja siihen, miten poliisi on työskennellyt ihmiskaupan vastaisten toimien kehittämiseksi sekä poliisin että oikeuslaitoksen sisällä. Poliisi on yhteistyössä sosiaaliviranomaisten ja kansalaisjärjestöjen kanssa myös kehittänyt auttamisjärjestelmän ihmiskaupan uhreille. Kjartansson esitteli, miten poliisia koulutetaan sekä ihmiskauppiaiden että ihmiskaupan uhrien tunnistamisessa. Nykyään on aivan selvää, että Islannissa on ihmiskauppaa, jopa naisia Afrikan maista lähetetään Islantiin seksuaalisesti hyväksikäytettäviksi.

Vuonna 2010 Islannin korkein oikeus antoi kaksi ensimmäistä tuomiotaan ihmiskaupasta ja seksuaalisesta hyväksikäytöstä. Yhdessä tapauksessa kyse oli afrikkalaisesta naisesta, joka oli houkutellut toisen naisen Islantiin ja myynyt hänen prostituoiduksi. Hän salakuljetti myös huumeita Islantiin, ja hänet tuomittiin vankeuteen 3 vuodeksi ja 6 kuukaudeksi. Toinen tapaus koski liettualaista tyttöä, joka lähetettiin Islantiin. Viisi Baltian maiden kansalaista tuomittiin ihmiskaupasta, yksi tuomittiin 5 vuodeksi vankeuteen ja neljä tuomittiin 4 vuodeksi vankeuteen.

Helmikuussa 2016 Islannissa käsiteltiin oikeudessa uutta ihmiskauppatapausta. Ulkomaalaista henkilöä syytettiin siitä, että hän haki kaksi naista Sri Lankasta Islantiin 
ja käytti heitä hyväkseen halpana työvoimana huonoissa työoloissa. Naiset eivät saaneet juuri mitään palkkaa työstään. Poliisille tapauksen tutkinta on ollut monimutkaista, koska on ollut vaikeaa määrittää, onko kyseessä pakkotyö vai huonot työolot ja alipalkkaus, vai työvoiman hyväksikäyttö.

Nämä tapaukset osoittavat selkeästi, että Islannissa on ihmiskauppaa, mutta poliisin on vaikeaa havaita tapauksia. Olennainen syy on se, että uhreilla ei ole tietoa oikeuksistaan tai että he erilaisista henkilökohtaisista syistä eivät halua päästä pois tilanteestaan tai tehdä yhteistyötä poliisin kanssa.

\section{Kuva 9: Olafur Kjartansson}

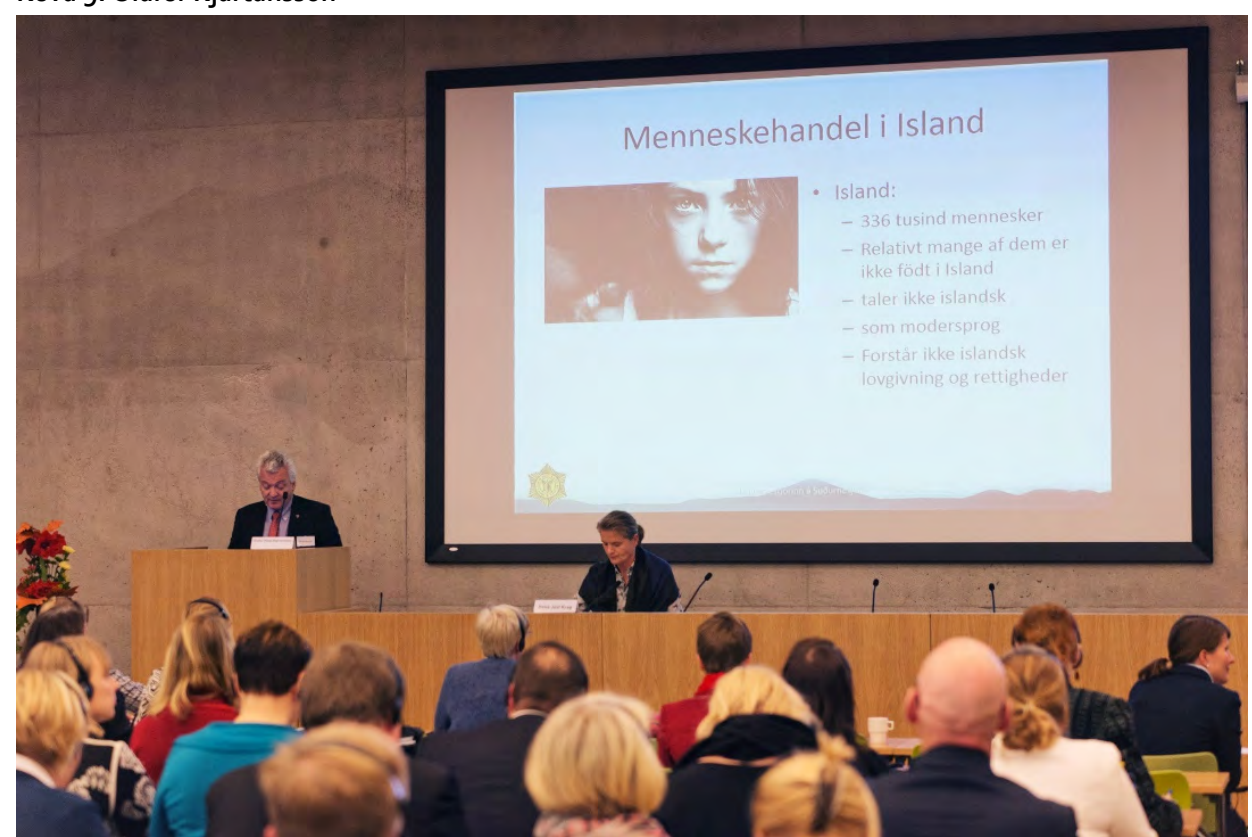

Poliisi epäilee usein, että muista maista tulevia työntekijöitä käytetään hyväksi työpaikalla, että he saavat pienempää palkkaa kuin islantilaiset tai että heidät pakotetaan asumaan surkeissa oloissa ja tavalla, jota islantilaiset missään tapauksessa eivät hyväksyisi. Kjartansson kertoi, että poliisi epäili jo vuonna 2003, että tapauksessa, joka koski islantilaista työnantajaa, joka oli rekrytoinut balttilaisia työntekijöitä Islantiin, oli kyse inmiskaupasta. Balttilaisilla työntekijöillä ei ollut työlupia, joita vielä vuonna 2003 vaadittiin Baltian maiden kansalaisilta Islannissa työskentelyyn. Balttilaiset tuomittiin laittomasta työskentelystä Islannissa. Poliisi ei voinut todistaa, että työnantaja oli rikkonut lakia. Balttilaiset saivat ehdollisen tuomion laittomasta työskentelystä Islannissa. Sekä työnantaja että balttilaiset työntekijät väittivät, että balttilaiset olivat Islannissa koeajalla saadakseen selville, halusivatko he työskennellä Islannissa. Tapaus osoittaa selkeästi, miten vaikeaa on todistaa rikollinen toiminta ihmiskaupan yhteydessä, kun henkilöt, joita käytetään hyväksi, eivät syystä tai toisesta halua tehdä yhteistyötä poliisin kanssa. Oli aivan selvää, että henkilöitä oli käytetty hyväksi ja että he eivät tunteneet oikeuksiaan eivätkä Islannin työlainsäädäntöä. Tämä johtuu usein siitä, että hyväksikäytettävät henkilöt tulevat maista, joissa työolot ovat 
huonot ja työttömyys korkea, ja katsovat kaiken näyttävän paremmalta uudessa maassa. Kjartansson sanoi tapauksen osoittavan myös, miten vaikeaa on saada pakkotyötapaus islantilaisen tuomioistuimen käsiteltäväksi.

Lapsiin liittyvät tapaukset ovat myös aiheuttaneet epäilyksiä ihmiskaupasta. Poliisi tutki tapausta, jossa balkanilainen mies tuli Islantiin nuoren pojan kanssa ja väitti pojan olevan oma poikansa. Poliisitutkinnassa kävi ilmi, että pojan kotimaassa tämän vanhemmat olivat ilmoittaneet pojan kadonneeksi. Todisteiden puutteessa miestä ei voitu syyttää.

Kjartansson sanoi, että Islannin poliisille on suuri haaste tunnistaa ihmiskaupan uhreja ja havaita tilanteita, joissa voidaan epäillä olevan kyse ihmiskaupasta. On tärkeää, että Islannin poliisi tekee yhteistyötä muiden viranomaisten ja asiantuntijoiden, kuten sosiaalineuvojien, psykologien, lääkärien ja opettajien, kanssa ja lisäksi muiden maiden kanssa ihmiskauppaan liittyvien tutkintojen yhteydessä. Ihmiskauppatapausten tutkiminen vaatii paljon poliisityötä, ja poliisilla on oltava käytettävissään erityistietoa ja asiantuntijoita voidakseen selviytyä näiden usein vielä erittäin monimutkaisten tapausten tutkinnasta. Erityisesti seksuaaliseen hyväksikäyttöön liittyvät tapaukset voivat olla hankalia tutkia.

Yleisölle tiedottaminen on tärkeää, jotta ihmiset voivat oppia tunnistamaan mahdollisia ihmiskauppatapauksia lähiympäristössään ja jotta voidaan selvittää ihmiskauppaan liittyvää problematiikkaa. Erityisen vaikeita ovat naisilla ja lapsilla tehtyyn ihmiskauppaan liittyvät tapaukset. Kjartansson päätti puheenvuoronsa sanomalla: "Vaikka ihmiskauppatapausten tutkiminen vaatii poliisilta paljon resursseja ja voi kestää kauan, poliisi on velvollinen tutkimaan tapauksia ja hyödyntämään nykyaikaista tekniikkaa mahdollisimman hyvin. Se on velvollisuutemme. Emme saa koskaan luovuttaa." 



\section{Aihe: Naiset ja miehet ihmiskaupan uhreina}

- Moderaattori: Mikko Sipilä, kihlakunnansyyttäjä, Itä-Uudenmaan syyttäjänvirasto, Suomi

\subsection{Hyväksikäytön psyykkiset seuraukset ja rikosprosessi}

Maija Koskenoja, ylitarkastaja, yhdenvertaisuusvaltuutetun toimisto, Suomi, esitteli suomalaisen mallitoimistotapauksen, jossa nuori nainen halusi tehdä uraa kansainvälisenä mallina. Hänestä otettiin ensimmäisessä työhaastattelussa vasten hänen omaa tahtoaan alastonkuvia. Mallitoimiston johtaja käytti alastonkuvia kiristyksenä, ja nainen pakotettiin myymään asiakkaille seksipalveluja, jotka johtaja välitti. Koskenoja esitti, miten tekijä saa uhrinsa valtaansa ja mitkä ovat ihmiskaupan ja seksuaalisen hyväksikäytön psyykkiset seuraukset uhreille ja näiden perheille. Johtaja antoi itsestään virheellisen kuvan vaikutusvaltaisena toimijana mallimaailmassa tosiasiassa hän johti yritystä, jolla oli eroottista ohjelmatarjontaa. Mallitoimistotapauksessa oli yhteensä 25 asianomistajaa. Johtajaa syytettiin tässä Koskenojan esittelemässä tapauksessa yhdessä syytekohdassa ihmiskaupasta ja yli 20 syytekohdassa erilaisista seksuaalirikoksista. Johtaja tuomittiin käräjäoikeudessa kaikista rikoksista yhteensä 25 asianomistajaa vastaan, sekä ihmiskaupasta että kymmenistä seksuaalirikoksista, yhteensä 12 vuoden ja 6 kuukauden vankeuteen. Korkein oikeus muutti tuomion yhteensä 10 vuodeksi ja 6 kuukaudeksi, hänet tuomittiin ihmiskaupasta ainoastaan yhden asianomistajan osalta. Mies tuomittiin maksamaan asianomistajille n. 200 ooo euron korvaukset.

Koskenoja sanoi, että oikeudenkäynnissä on käytettävä asiantuntijatodistajia, jotta tuomioistuin uskoo uhrin kertomuksen todeksi. Hän painotti, että asiantuntijatodistajia on käytettävä rikosprosessissa, jotta todistelu ja todisteiden arvioiminen takaavat uhreille oikeudenmukaisen käsittelyn, ja jotta uhrit voivat saada korvausta kärsimistään vahingoista. Uhri asui kotona, kävi koulua, suoritti ylioppilastutkinnon eli oli mallioppilas, ja samaan aikaan jatkui uhrin seksuaalinen hyväksikäyttö ja manipulointi. Uhri oli ottanut yhteyttä poliisiin saadakseen apua sopimuksen purkamisessa, mutta poliisi oli sanonut vain, että hän oli törmännyt huijariin ja saanut huonon työsopimuksen. Uhrin käyttäytymisen ymmärtämiseksi tarvitaan asiantuntijatodistajia, kuten terapeutteja ja asiantuntijoita psykiatrian poliklinikalta ja oikeuspsykiatrian yksiköstä, joissa uhri on käynyt ja ollut hoidettavana. Oikeudessa on kuvailtava seksuaalisen hyväksikäytön dynamiikkaa terapeuttisen ja psyykkisen hoidon sekä seksuaalisen hyväksikäytön seurauksia koskevan tieteellisen 
näytön pohjalta. Oikeudenkäynnissä on tärkeää ottaa esiin seuraavanlaisia kysymyksiä: Mitä tarkoittaa manipulaatio? Liittyykö hyväksikäyttöön häpeää ja syyllisyyttä? Onko kokemusperäisesti tunnettua, että hyväksikäytetty ei pakene, huuda, lähde pois tilanteesta?

Koskenoja kuvaili, miten hyväksikäyttöä arvioitiin eri oikeusasteissa. Helsingin käräjäoikeus (2011) katsoi, että esitetyn näytön perusteella tunnusmerkistötekijät olivat täyttyneet ja että mallitoimiston johtaja oli syyllistynyt ihmiskauppaan. Johtopäätös oli, että uhrilla oli vakavia traumaoireita, jotka asiantuntijoiden mukaan olivat tyypillisiä hyväksikäytetylle henkilölle. Seuraava oikeusaste Helsingin hovioikeudessa (2013) katsoi, että uhrin psyykkisen terveydentilan häiriintyminen oli johtunut vastaajan menettelystä ja perustui siihen, että uhri on ollut vastaajan vallan alla. Suomen korkeimmalla oikeudella (2015) oli erilainen käsitys: se katsoi, että ihmiskauppasäännöksen tunnusmerkistötekijä "ottaa valtaansa" ei täyttynyt mallitoimistotapauksessa. Koskenoja sanoi, että korkein oikeus ei järjstänyt suullista käsittelyä, kuten kaksi ensimmäistä oikeusastetta, vaan oli ainoastaan perehtynyt kirjalliseen aineistoon. Näin ollen korkeimman oikeuden jäsenet eivät olleet itse tekemisissä uhrin kanssa eivätkä voineet arvioida hänen psyykkistä tilaansa. Koskenoja totesi, että tarvitaan muun muassa muutoksia lainsäädäntöön, uhrikäyttäytymisen ja traumatisoitumisen ymmärtämistä sekä rakennetta psyykkisen tilan arviointia varten. Koskenoja sanoi, että eri viranomaisissa tarvittaisiin asiantuntijaryhmiä, joilla on asiantuntemusta ja kokemusta rekrytoinnista, hyväksikäytöstä ja ihmiskaupan torjumisesta. Koko tapaus vei 6 vuotta uhrin elämästä, hänen psyykkinen tilansa oli koko ajan heikko ja hän oli hoidettavana psykiatrisessa sairaalassa. Tapaus on myös vaikuttanut uhrin perheeseen, ja seurauksia ovat olleet vaikeudet koulunkäynnissä ja työelämään osallistumisessa. Nykyään lainsäädäntöä on muutettu siten, että siinä otetaan paremmin huomioon tekijän psykologian ymmärtäminen.

Tämä konkreettinen tapaus Suomesta kertoo, miten ihmiskauppaa voi tapahtua myös maan sisällä, ja että ihmiskaupan ei tarvitse olla rikollista rajat ylittävää toimintaa, jonka on tapahduttava maasta toiseen. Koskenoja toi esiin myös sen, että seksuaalisessa hyväksikäytössä tapahtuvassa ihmiskaupassa on selkeä sukupuolinäkökulma ja että useimmissa seksuaalisen hyväksikäytön tapauksissa uhri on nainen tai tyttö ja seksipalveluja ostaa mies. Ihmiskauppiaat ja naisia rekrytoivat henkilöt voivat olla sekä naisia että miehiä.

\subsection{Saavatko uhrit - naiset ja miehet - tarvitsemansa avun?}

Leila Langdalen Sbai, viestinnän neuvonantaja, ROSA, Oslon kriisikeskus, Norja ja Kristin Berntsen, tiiminvetäjä, Mottak, Oslon kriisikeskus, Norja, kertoivat esityksessään järjestöjen työstä ihmiskaupan uhrien auttamiseksi ja avusta, jota uhrit, sekä naiset että miehet, voivat saada ottaessaan yhteyttä ROSAan ja Mottakiin Oslon kriisikeskuksessa.

Leila Langdalen Sbai aloitti kertomalla, miten ROSA ja Oslon kriisikeskus tekevät yhteistyötä yli 18-vuotiaiden ihmiskaupan uhrien auttamiseksi ja suojelemiseksi. 
ROSAlla oli aluksi kaksi vakituista työntekijää, ja nyt se on uuden puhelintukipalvelun ansiosta saanut vielä yhden avustajan. Toimintaa rahoittaa Norjan oikeusministeriö. ROSAn tehtävä on auttaa ihmiskaupan uhreiksi joutuneita ja prostituutiossa hyväksikäytettyjä henkilöitä, joilla ei ole omaa asuntoa, ja taata heille turvallinen majoitus. Työ tapahtuu sekä puhelimitse että Oslossa myös henkilökohtaisten keskustelujen avulla. ROSA ohjaa uhreja kriisikeskuksiin kaikkialla Norjassa. Useimmat uhreista tulevat ROSAan poliisin lähettäminä. ROSA on tukenut ja auttanut yli 1 ooo:ta henkilöä, ja yhteensä 500 henkilöä on osallistunut ROSAn projekteihin.

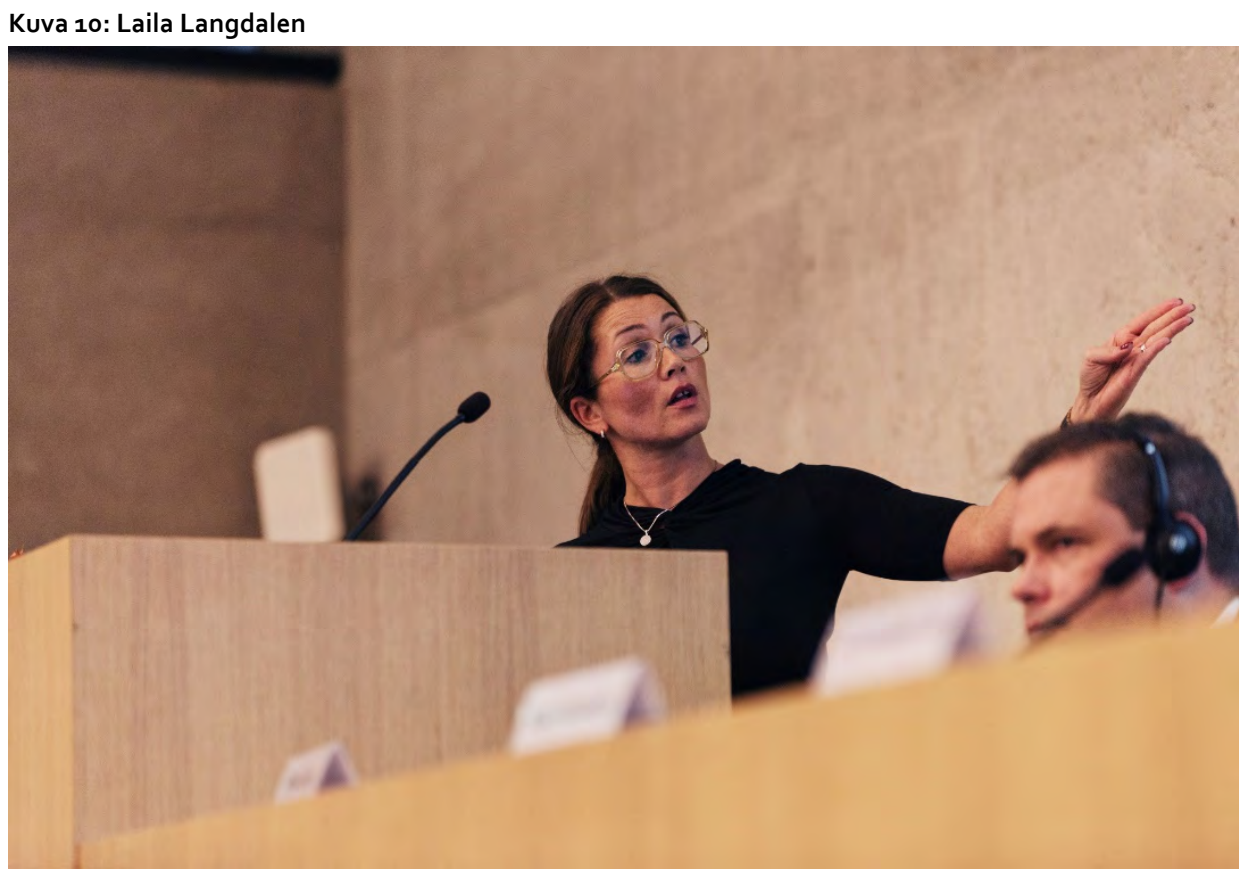

ROSA myös avustaa poliisia, asianajajia ja ihmiskauppaa torjuvia järjestöjä, opettaa myös poliisikorkeakoulussa ja toimittajakorkeakoulussa ja levittää tietoa ihmiskaupasta. Landalen Sbai sanoi, että useimmat naiset tulevat Nigeriasta, Albaniasta, Bulgariasta, Romaniasta ja muista Itä-Euroopan maista. Yhteensä ROSA on ollut yhteydessä 6o maasta kotoisin oleviin henkilöihin. Nigerialaisten ryhmä on ollut suurin viime vuosina. Useimmat uhrit ovat 20-30-vuotiaita, mutta näyttää siltä, että uhrit ovat nykyään yhä nuorempia, ja monet ovat alaikäisiä. Useimmat uhreista tulevat Norjaan Italiasta, Espanjasta, Tanskasta ja Ruotsista, heillä ei ole papereita, heillä on suuret velat ja heitä kontrolloidaan fyysisen, psyykkisen ja seksuaalisen väkivallan avulla. Nigerialaisten ryhmään kohdistuu myös juju, joka on erittäin tehokas kontrollointikeino. Vuosina 2014-2016 ROSAan on ottanut yhteyttä myös ihmiskaupan uhreiksi joutuneita miehiä. Yhteensä 78 ROSAan kohdistuneista ensikontakteista vuonna 2016 yhteensä seitsemän oli miehiä, joita oli käytetty hyväksi työmarkkinoilla. Landalen Sbai kertoi, että miehillä on korkeampi kynnys ottaa yhteyttä kriisikeskukseen, mutta että miehet ovat myös saaneet tarjouksia turvallisesta majoituksesta. Hän sanoi, että vuonna 2016 ROSA antoi myös ensimmäistä kertaa 
apua transhenkilölle. Hän kuvaili myös erilaisia lapsiryhmiä, joita oli tullut Norjaan vuosina 2014-2015. Landalen Sbai päätti puheenvuoronsa sanomalla, että ROSA on riippuvainen siitä, että muut lähettävät ihmiskaupan uhreja sinne, koska se ei itse tee etsivää työtä. Tänä päivänä on suuri tarve ihmiskauppaa koskevalle tiedolle.

Kristin Berntsen esitteli Oslon kriisikeskuksen toimintaa ja aloitti kuvailemalla Norjan kriisikeskuksia koskevaa lainsäädäntöä vuodelta 2010, joka velvoittaa Norjan kaikki kunnat auttamaan naisia, miehiä ja lapsia, jotka ovat joutuneet väkivallan uhreiksi lähisuhteessa. Kriisikeskus on avoinna vuorokauden ympäri, ylläpitää puhelinneuvontaa ja tarjoaa suojattua majoitusta. Kriisikeskuksessa on suojatun majoituksen osasto, päiväosasto, jolla annetaan neuvontaa väkivallan eri muotojen uhreiksi joutuneille naisille, osasto väkivallan uhreiksi lähisuhteessa joutuneille miehille sekä ROSA-osasto, joka auttaa ihmiskaupan uhreja koko Norjassa. Oslon kriisikeskus on Pohjois-Euroopan suurin kriisikeskus, ja keskuksessa asuu vuosittain 350 naista ja 300 lasta. Miesten osastolla asui vuoden 2015 aikana yhteensä 15 miestä ja 5 poikaa. ROSA-osastolla asuu vuosittain 30-40 ihmiskaupan uhria. Oslon kriisikeskukseen ottaa vuosittain yhteyttä 175-200 henkilöä. Elokuusta 2016 alkaen apua ovat voineet saada ihmiskaupan kaikkien muotojen uhrit, eivät ainoastaan ne, joita on käytetty hyväksi seksuaalisesti. Kriisikeskus hoitaa yhdessä ROSAn kanssa uhrin lopullisen tunnistamisen. Yhteyshenkilö seuraa uhria koko rikosprosessin läpi. Berntsen sanoi myös, että psyykkiset ja sosiaaliset seuraukset uhreille ovat samanlaisia kuin väkivallan uhreiksi joutuneiden naisten kohdalla. Asuessaan ROSA-osastolla ihmiskaupan uhrit saavat oikeudellista apua, terveydenhoitoa ja koulutustarjouksen voidakseen rakentaa itselleen tulevaisuuden Norjassa.

\section{Kuva 11: Kristin Berntsen}

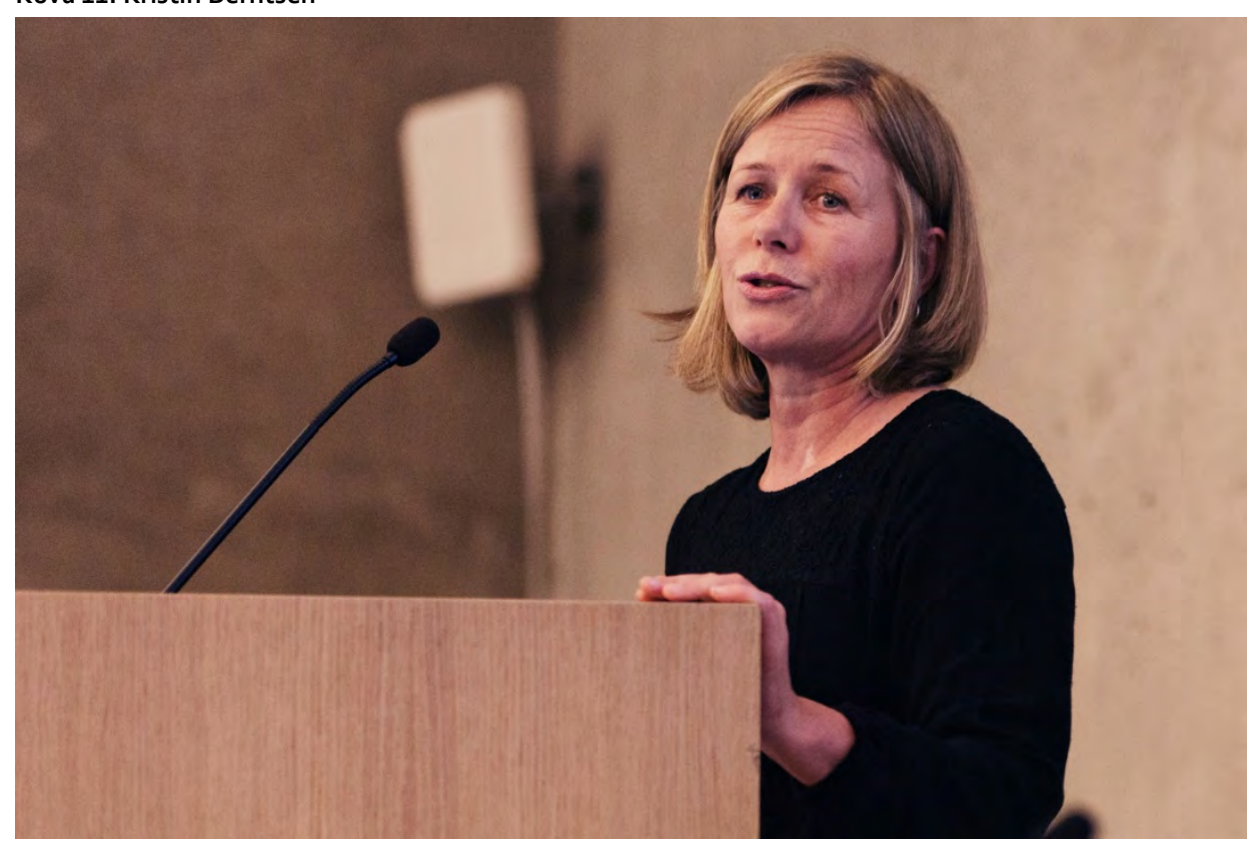




\section{Paneelikeskustelu}

\subsection{Miten Pohjoismaat voivat tehdä yhteistyötä ihmiskauppaa vastaan?}

- Moderaattori: Eva Biaudet, kansanedustaja, Suomi.

Paneelin osanottajat:

- Anna Katrine Krag Madsen, analyytikko, Kööpenhaminan poliisi, Tanska

- Malene Muusholm, tiiminvetäjä, Reden København/Reden International, Tanska

- Laura Sairanen, kihlakunnansyyttäjä, valtakunnansyyttäjänvirasto, Suomi

- Kenneth Eriksson, ylikonstaapeli, Helsingin poliisilaitos, Suomi

- Olafur Helgi Kjartansson, poliisipäällikkö, Suðurnesin poliisipiiri, Islanti

- Thor Martin Elton, poliisitarkastaja, Oslon poliisipiiri, Norja

- Helena Ljunggren, kamarisyyttäjä, Malmön kansainvälinen syyttäjäkamari, Ruotsi

\section{Kuva 12: Eva Biaudet}

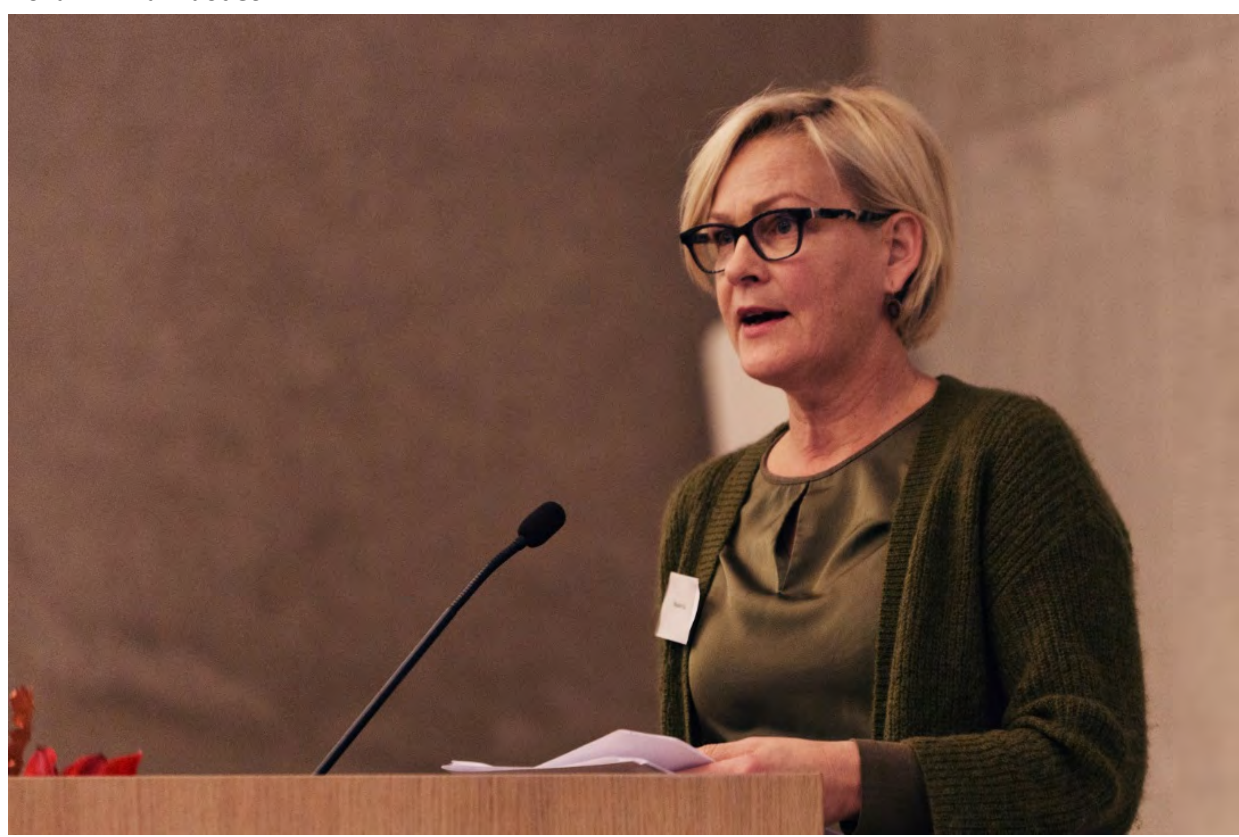


Paneelikeskustelun lähtökohtana toimivat seuraavat kysymykset:

- Mitä ihmiskauppaa vastaan työskentelevät toimijat voivat oppia toisiltaan?

- Miten asiantuntijat voivat parhaiten vaihtaa kokemuksia, työmenetelmiä ja tietoa?

- Miltä yhteistyö rajat ylittävissä tutkinnoissa voisi näyttää käytännössä?

Paneelin aluksi Anna Katrine Krag Madsen, analyytikko Kööpenhaminan Vestegnin poliisissa Tanskassa, esitteli pohjoismaisen raportin Exchange of Information in Cases of Trafficking in Human Beings (TemaNord 2016:542, Pohjoismaiden ministerineuvosto), jonka rahoitti Pohjoismaiden ministerineuvosto ja kokosi Rigspolitiets Nationale Efterforskningscenter (NEC) vuosina 2015-2016. Lue raportti:

- http://norden.diva-portal.org/smash/ record.jsf?pid=diva2\%3A971195\&dswid=81\#sthash.qfGcPCY6.dpbs

Kuva 13: Anna Katrine Krag Madsen

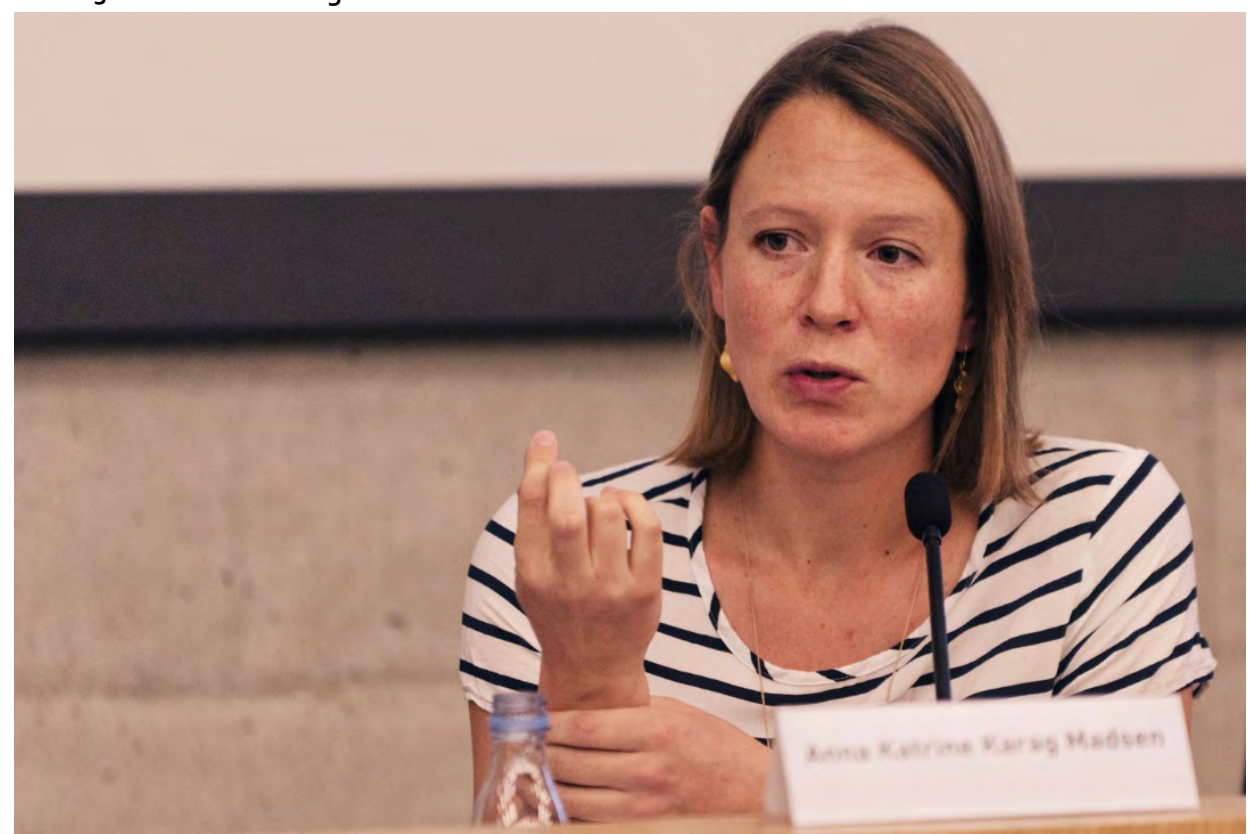

Raportissa esitetään tietoa siitä, miten Pohjoismaiden eri viranomaiset ja poliisi vaihtavat tietoa. Viranomaiset, jotka osallistuivat tutkimukseen ja käsittelevät päivittäin tietoa ihmiskaupasta, katsovat, että heidän on harvoin otettava yhteyttä poliisiin ja jos he ottavat yhteyttä poliisiin, he kysyvät koordinoivaa yksikköä varmistuakseen siitä, että tieto menee perille oikeaan yksikköön poliisin sisällä. Harvat kansallisista viranomaisista ovat katsoneet tarpeelliseksi ottaa yhteyttä muiden Pohjoismaiden viranomaisiin ihmiskauppakysymyksissä. Mikäli on ollut tarpeen ottaa yhteyttä toiseen Pohjoismaahan, ne ovat ottaneet yhteyttä maan poliisiin. Raporttiin 
osallistuneet poliisiviranomaiset ovat kertoneet, että niiden tehtävä on vaihtaa tietoja muiden poliisiviranomaisten kanssa. Raportissa ehdotetaan seuraavanlaista tiedonvaihtoa Pohjoismaiden välillä:

- Koulutus ihmiskaupan indikaattoreiden käytössä.

- Selkeät viestintäkanavat viranomaisten ja poliisin välillä.

- Ihmiskaupan sisäisen käsittelyn organisatorinen priorisointi viranomaisissa ja poliisissa.

Pohjoismaiden ministerineuvosto on myös julkaissut raporttiin perustuvan hyvien käytäntöjen oppaan. Lue raportti:

- http://norden.diva-portal.org/smash/record.jsf?pid=diva2\%3A971227\&dswid=2775\#sthash.BFkb7jbp.dpbs

Paneelin osanottajat kertoivat lyhyesti näkökulmastaan ihmiskaupparikollisuuteen ja haasteista, joita poliisi, syyttäjäviranomainen ja kansalaisjärjestöt kohtaavat uhrien tunnistamisen yhteydessä ja erityisesti pyrkiessään vakuuttamaan uhreja siitä, että heidän kertomuksensa ja todistajanlausuntonsa ovat tärkeitä rikosprosessin kannalta. Paneelissa painotettiin, että poliisin ja syyttäjien välillä vaaditaan hyvää yhteistyötä ja että pohjoismainen yhteistyö olisi hyvä asia, koska ihmiskaupan uhreja kuljetetaan nykyään Pohjoismaasta toiseen.

Malene Muusholm tanskalaisesta Reden International-järjestöstä kertoi, että Reden tekee etsivää työtä kaduilla Kööpenhaminassa ja että Redenille on tärkeää luoda pitkäaikainen suhde kohtaamiinsa naisiin. On tärkeää, että Redenissä on myös ihmisiä, jotka puhuvat naisten kieltä ja ymmärtävät oloja maissa, joista he tulevat. Muusholm katsoi, että voisi olla hyvä rakentaa muidenkin järjestöjen ja viranomaisten kanssa samankaltaista ihmiskauppaan liittyvää yhteistyötä, kuin mitä Operation Hvepsebon tutkinnan yhteydessä toteuttiin. Yhteistyö on erityisen tärkeää nigerialaisten naisten kohdalla, sillä heitä lähetetään ja he matkustavat ympäriinsä Pohjoismaiden välillä. Redenillä on yhteistyötä pohjoismaisten järjestöjen kanssa, mutta Reden ottaa ensi kädessä yhteyttä poliisiin, kun se haluaa yhteyden toiseen Pohjoismaahan tai tietoja sieltä.

Olafur Helgi Kjartansson sanoi, että poliisin pitäisi käynnistää yhteistyö koulujen ja terveydenhoidon kanssa ihmiskaupan torjumiseksi. Poliisi ei aina onnistu saamaan tietoja muilta viranomaisilta, muun muassa lääkärit eivät halua antaa tietoja poliisille vaan viittaavat vaitiolovelvollisuuteen. Nigerialaiset naiset eivät myöskään halua tehdä yhteistyötä poliisin kanssa. Usein uhreilla ja asiantuntijoilla on tietoja, jotka voisivat auttaa poliisia tutkimaan ihmiskaupparikoksia. Kjartansson sanoi myös, että vähintään viidessä huumeiden salakuljetustapauksessa Islannissa vaikuttaa siltä, että ulkomaalaisia naisia on pakotettu salakuljettamaan huumeita Islantiin ja että kyse on ihmiskaupasta, mutta Islannin poliisi ei ole pystynyt todistamaan, että kyse on ihmiskaupasta. 
Kenneth Eriksson Helsingin poliisista sanoi, että hän työskentelee ihmiskaupan ja prostituution parissa ja että Suomessa on ongelmana se, ettei poliisi ole erikoistunut inmiskauppaan. Pitkällä aikavälillä pitäisi saada aikaan ryhmä tai ryhmiä, jotka erikoistuvat ihmiskaupparikoksiin ja hoitavat niiden esitutkinnan. Poliisi työskentelee kentällä, ja sen on kaivettava tapaukset esiin ja saatava uhrit kertomaan tarinansa. Ihmiskaupparikokset ovat pitkiä ja vaikeita projekteja, jotka vievät aikaa, ja inmiskauppatapauksia tutkittaessa on oltava erittäin kärsivällinen. Poliisi on myös yhteydessä kolmannen sektorin järjestöihin. On myös löydettävä ne poliisit, jotka ovat kiinnostuneita työskentelystä ihmiskaupparikosten parissa. Poliisi ei voi tehdä tätä yksin, vaan tarvitaan tiimi; poliiseja, hyvä syyttäjä, osaava tuomari ja yhteyksiä järjestöihin, jotka työskentelevät ihmiskaupan torjumisen parissa. Ihmiskaupan torjumiseksi tarvitaan myös rajat ylittävää yhteistyötä. Tänä päivänä onkin helppoa ottaa yhteyttä muiden Pohjoismaiden poliiseihin, jotka työskentelevät ihmiskaupan torjumisen parissa. Eriksson päätti puheenvuoronsa seuraavasti: "Meidän on alettava panostaa tähän. Tarvitsemme enemmän ihmisiä, jotka toimivat kentällä."

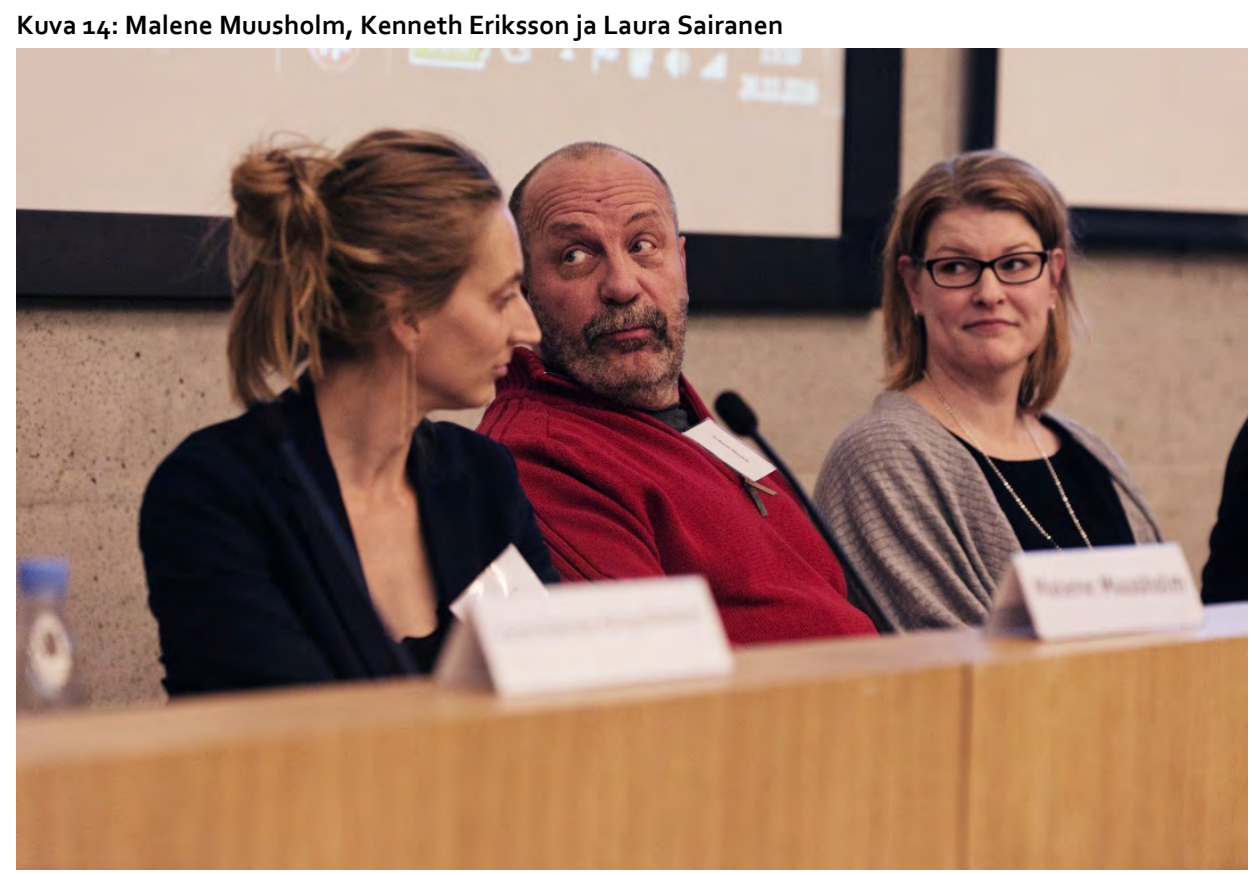

Laura Sairanen, kihlakunnansyyttäjä valtakunnansyyttäjänvirastossa Suomessa, painotti, että jos ihmiskaupparikoksia tutkivat poliisit ymmärtävät, mitä inmiskauppa on, ja ovat perehtyneet tutkittavaan tapaukseen, syyttäjän on helpompaa viedä tapaus tuomioistuimeen. Sairanen sanoi, että tulkkien kanssa on ollut ongelmia; he eivät aina ole tulkanneet sitä, mitä syyttäjä ja poliisit sanovat vaan myös esittäneet omia näkemyksiään uhreille. Siksi on äärettömän tärkeää saada oikeudenkäynteihin hyviä tulkkeja. Jos oikeudenkäynnin tuomari ei ymmärrä, mitä ihmiskauppa on, prosessista tulee hankala syyttäjälle, jonka on selitettävä kaikki, ja usein voi syntyä erimielisyyksiä kaikista käsitteistä. 
Thor Martin Elton, poliisitarkastaja Oslon poliisipiirissä Norjassa, sanoi, että nykyään Oslon poliisilla on erikoisyksikkö, joka on osa järjestäytyneen rikollisuuden yksikköä ja toimii yksinomaan ihmiskaupan parissa. Aiemmin ihmiskauppa oli projekti eikä saanut samanlaista huomiota, ja ihmiskauppaa koskevat tutkinnat joutuivat usein alimmaisiksi tutkittavien rikosten pinossa. Elton esitteli Tukholman poliisin kanssa tehtyä yhteistyötä, jossa oli kyse taskuvarasryhmästä, joka oli junassa matkalla Osloon. Oslon poliisin asiantuntijaryhmä seurasi ryhmää ja näki, että kaksi tyttöä hoiti näpistelyt ja täysi-ikäiset henkilöt seurasivat tyttöjen näpistelyä. Tukholman poliisi oli katsonut, että oli omituista, että 12-vuotiaat tytöt syyllistyivät rikoksiin. Norjan poliisi keräsi todisteita video- ja valvontakameroiden avulla. Kävi ilmi, että tytöistä ei ollut sormenjälkiä, koska Ruotsi ei ota sormenjälkiä alle 15-vuotiailta lapsilta. Se tarkoitti, ettei poliisilla ollut tietoa siitä, oliko poliisi muissa Pohjoismaissa tai Euroopan maissa ottanut tyttöjä kiinni. Norjan poliisi sai tietoja siitä, että ryhmä oli ollut aktiivinen monissa Euroopan maissa. Kävi myös ilmi, että osa ryhmästä oli lähetetty Pohjoismaihin selvittämään, miten viranomaiset reagoivat tämänkaltaisissa tilanteissa. Elton painotti, että on äärimmäisen tärkeää, että poliisi tällaisissa tapauksissa voi helposti ottaa suoraan yhteyttä muiden Pohjoismaiden poliiseihin. Hän sanoi olevan ongelmallista, että alaikäisiltä ei aina oteta sormenjälkiä, ja että rikosten rekisteröiminen ylipäänsä aiheuttaa ongelmia, sillä lapsia käytetään hyväksi rikosten toteuttamisessa. Jos rikoksia ei rekisteröidä, tämäntyyppisten tapausten tutkinnasta tulee erityisen hankalaa, erityisesti jos uhrit eivät halua tehdä yhteistyötä. Näihin lapsiuhreihin liittyvä haaste on se, että heillä on usein vahvat siteet rikoksentekijöihin. Usein rikoksentekijä on ainoa aikuinen lapsen elämässä.

Kuva 15: Thor Martin Elton

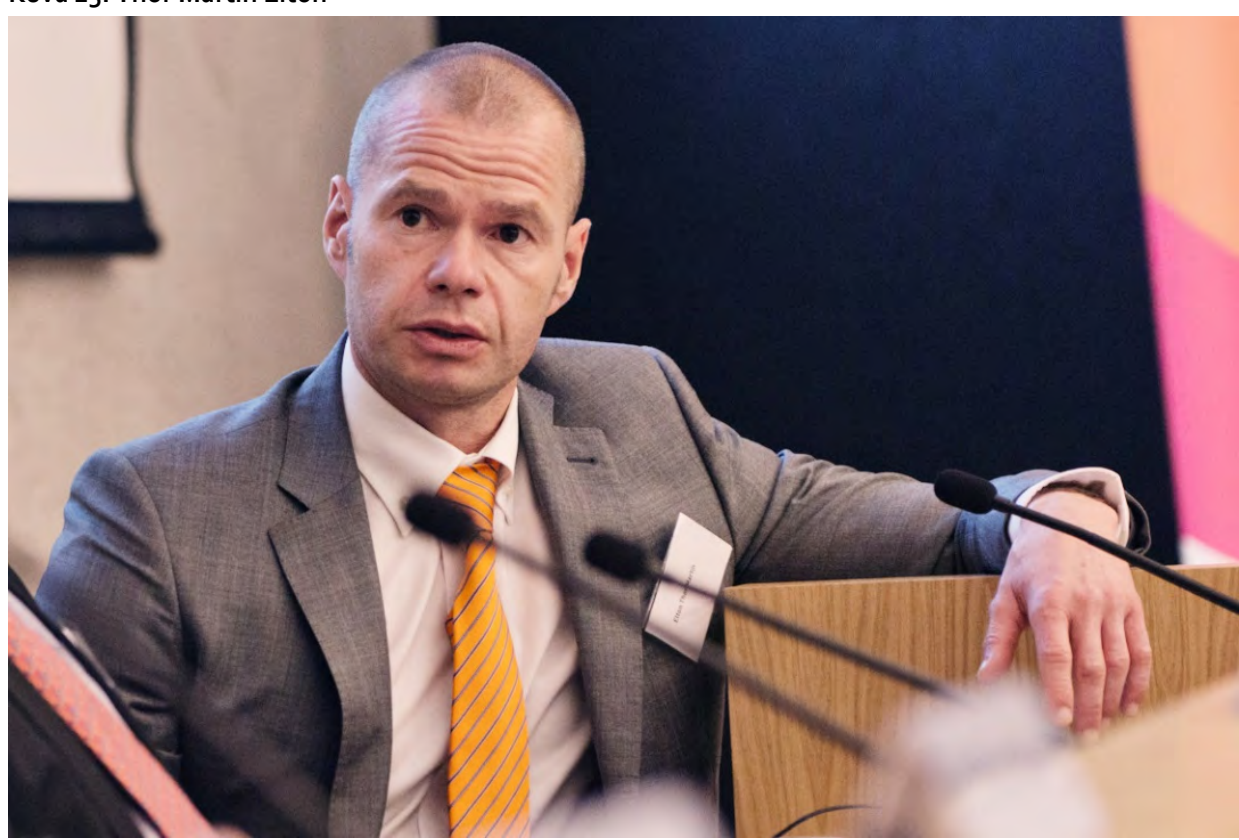


Helena Ljunggren, kamarisyyttäjä Malmön kansainvälisessä syyttäjäkamarissa Ruotsissa, sanoi, että Malmössä on asialle omistautuneita tutkijoita, jotka ymmärtävät, mitä rikollisuutta ihmiskauppa on, ja jotka ymmärtävät lainsäädäntöä. Poliisissa on myös tarkkailijoita, jotka ymmärtävät, mistä on kyse, ja voivat saada tietoja kentällä hoitamiensa tarkkailutehtävien aikana. Ljunggren painotti myös, että ihmiskaupparikoksiin liittyvien todisteiden kerääminen vaatii kärsivällisyyttä. Monet hyvät asianajajat avustavat uhreja oikeudenkäynneissä ja toimivat rikoksen uhrin puolesta. Asianajajien on oltava hyvä tuki uhrille ja oltava uhrin rinnalla ensimmäisestä poliisikuulustelusta alkaen. Asianajajan on autettava uhria luottamaan tapauksen parissa työskenteleviin poliiseihin ja syyttäjiin ja autettava uhria ymmärtämään, miksi on tärkeää, että hän kertoo tarinansa. Niitä rikoksen uhreja, jotka ovat päättäneet palata kotimaahansa, on kuulusteltava heidän kotimaassaan, ja tällöin on ollut hyvä, että ruotsalainen asianajaja on lähtenyt mukaan avustaakseen ihmiskaupan uhreja kuulusteluissa. Ljunggren kertoi, että työssään ihmiskaupparikosten syyttäjänä häntä on vaivannut se, ettei hän ole saanut yhteyttä kollegoihin muissa maissa samaan tapaan kuin työskennellessään huumetapausten ja ihmisten salakuljetukseen liittyvien rikosten parissa. Koska Ruotsissa ei olla tyytyväisiä ihmiskaupparikosten parissa saatuihin tuloksiin, siellä arastellaan antaa resursseja ihmiskaupparikosten tutkintaan, koska ei olla vakuuttuneita siitä, onnistuuko rikosten selvittäminen.

Kuva 16: Helena Ljunggren

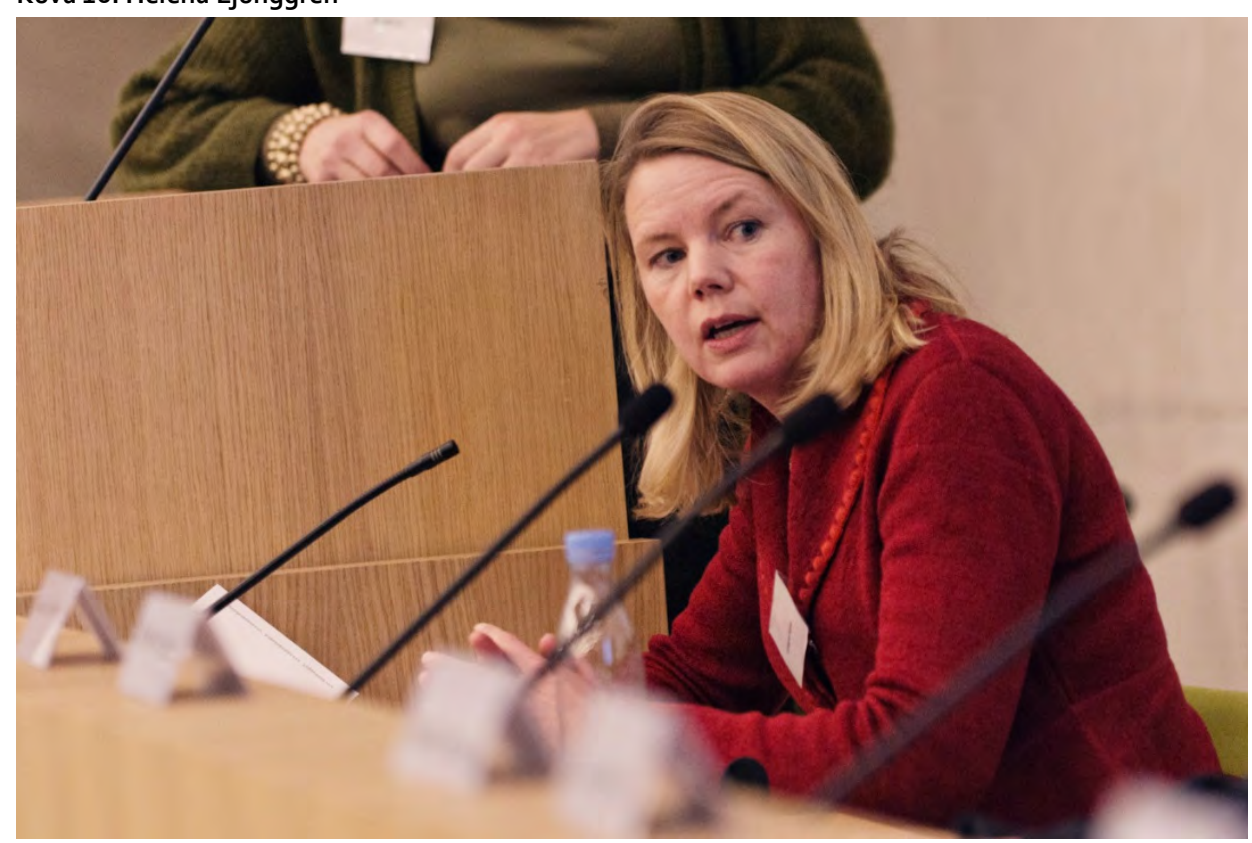

\subsection{Kooste paneelikeskustelusta}

Eva Biaudet totesi, että ihmiskaupparikosten tutkinnan haasteena kaikissa pohjoismaissa on nykyään se, että tutkinnalle jaetaan vain vähän resursseja, mikä 
johtaa siihen, että ihmiskaupparikosten tutkintaa ei aseteta etusijalle. Tämä taas johtaa siihen, että poliisin sisällä ei kehitetä erityistietoja ja osaamista, joita tarvitaan ihmiskaupparikosten tehokkaassa tutkinnassa. Ihmiskauppa on monimutkainen ala, ja siksi kaikissa inmiskauppatapauksiin osallistuvissa viranomaisissa tarvitaan asiantuntijoita, joilla on erityisosaamista, poliisista, syyttäjistä ja tuomareista uhrien auttamisjärjestelmiin ja sosiaali- ja terveyssektoriin sekä kansalaisjärjestöihin.

Paneelissa todettiin, että Pohjoismaat ovat pieniä maita ja hyötyvät yhteistyöstä, erityisesti koska Pohjoismaat ovat rakenteeltaan samankaltaisia, jonka vuoksi myös inmiskauppiaat käyttävät samoja menetelmiä kaikissa Pohjoismaissa. Pohjoismainen yhteistyö voisi toimia siten, että järjestettäisiin vuosittaisia asiantuntijatapaamisia niille, jotka työskentelevät päivittäin ihmiskaupan torjumisen vuoksi. Pohjoismaiden poliitikoilla on liian vähän tietoa ihmiskaupasta. Heitä pitäisi ottaa enemmän mukaan näihin kysymyksenasetteluihin ja Pohjoismaissa järjestettäviin konferensseihin. Ihmiskaupasta tarvitaan enemmän tietoa eri näkökulmista nähtynä, erityisesti poliisin ja oikeuslaitoksen sisällä, mutta myös muissa viranomaisissa ja järjestöissä, jotka työskentelevät ihmiskaupan torjumiseksi, sekä niiden asiantuntijoiden parissa, jotka ovat yhteydessä ihmisiin, jotka ovat ihmiskaupan eri muotojen uhreja.

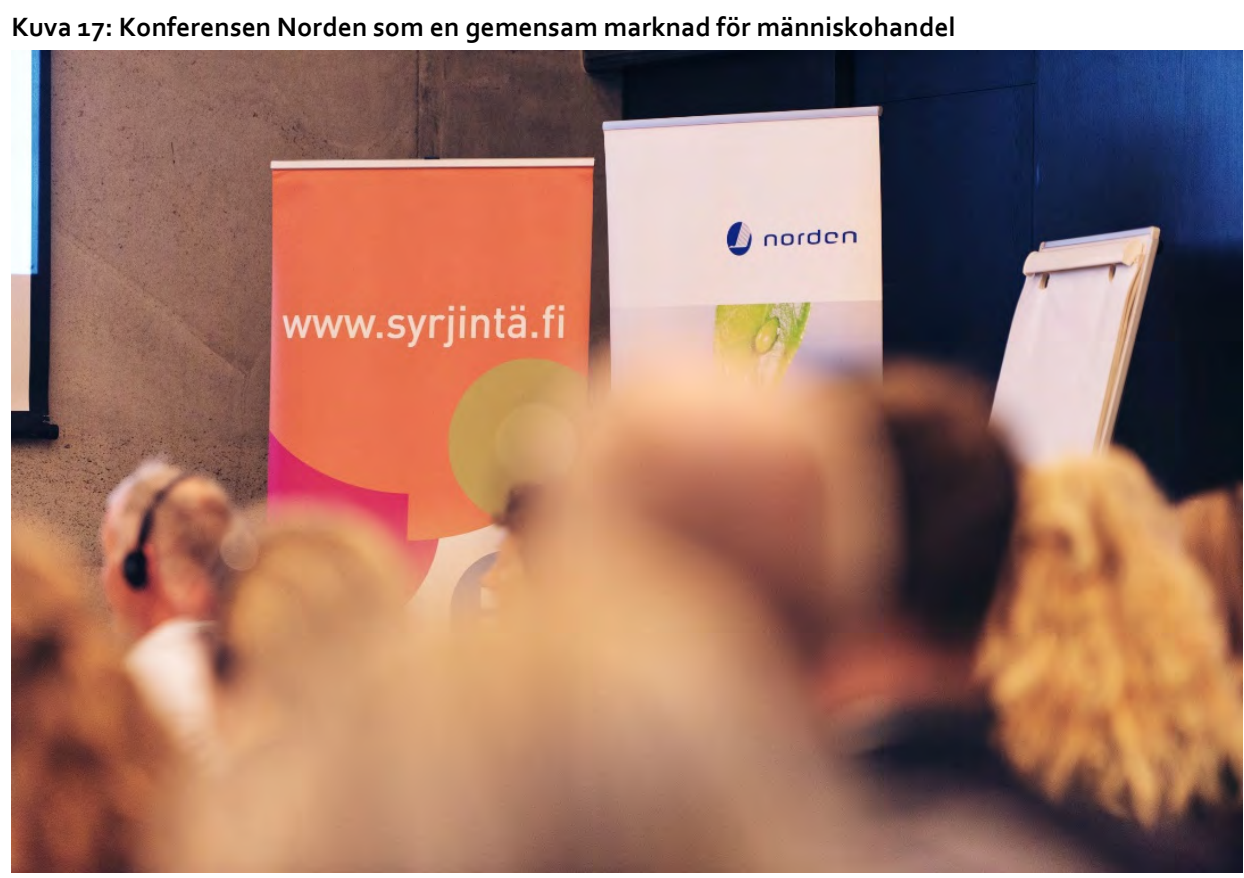





\section{Yhteenveto}

Ihmiskauppa on tämän päivän modernia orjuutta ja antaa Pohjoismaiden kaikille viranomaisille, järjestöille, asiantuntijoille ja vapaaehtoisille haasteita ihmiskaupan torjumisessa. Ihmiskauppiaat ja rikolliset kehittävät kaiken aikaa uusia menetelmiä ja ovat siten useita askelia edellä, koska lainsäädännöllä ja oikeuslaitoksella ei ole mahdollisuutta päivittää menetelmiään ihmiskaupan vastaisissa toimissa. Tämä johtaa siihen, että poliiseilla ja syyttäjillä ei aina ole riittäviä työkaluja ihmiskaupan uusimpien suuntausten torjumiseen. Tänä päivänä näemme Pohjoismaissa uusia suuntauksia, kuten köyhien ihmisten hyväksikäyttöä etuuksien hankkimiseen väärin perustein ja inmiskauppiaita, jotka pakottavat naisia ja miehiä, tyttöjä ja poikia tekemään rikoksia. Tämä johtaa siihen, etteivät poliisi ja syyttäjät aina pysty erottamaan, kuka on rikollinen ja kuka on ihmiskaupan uhri. Ihmisiä pakotetaan myös työskentelemään ilman korvausta siivous- ja rakennusalalla, ravintoloissa, maataloudessa, marjanpoimijoina ja kerjäläisinä. Lapsia käytetään seksuaalisesti hyväksi yhdessä maassa. Tekijät voivat ympäri maailmaa osallistua hyväksikäyttöön verkossa antamalla ohjeita omien seksuaalisten mieltymystensä mukaisesti siitä, miten hyväksikäyttö on toteutettava. Rikoksen tapahtuessa monissa maissa samanaikaisesti, johtaa se haasteisiin, koska rikollisuus on rajatonta, kun taas rangaistusjärjestelmät ovat kansallisia. Tällöin herää kysymys: Missä rikosta käsitellään?

Asiantuntijatodistajien käyttämisestä oikeudenkäynneissä sen ymmärtämiseksi, miten tekijät saavat uhrinsa valtaansa, tulee yhä tärkeämpää, koska tuomioistuimen on ymmärrettävä tilanne, johon ihmiskaupan uhrit joutuvat. Ihmiskauppiaat käyttävät kiristystä saadakseen uhrit jatkamaan heidän laskuunsa työskentelemistä. Seksuaalisen hyväksikäytön uhreja kuvataan heidän myydessään seksiä asiakkaille. Uhreja voidaan myös uhata sillä, että ihmiskauppiaat vahingoittavat heidän lapsiaan ja/tai vanhempiaan, jotka asuvat edelleen uhrin kotimaassa, tai jopa tappavat heidät. Tämä johtaa usein siihen, että uhrit eivät uskalla ryhtyä todistajiksi oikeussalissa, ja tällöin syyttäjien ja poliisin on vaikeaa saada riittäviä todisteita ihmiskaupparikoksista. Paneelissa painotettiin useaan kertaan, että on tärkeää saada uhrit kertomaan tarinansa, koska uhrin kertomus on usein vahvin todiste siitä, että uhria on käytetty hyväksi ihmiskaupassa. Tämä tarkoittaa, että tuomioistuinten on otettava käyttöön uusia menetelmiä, jotta uhrit voivat todistaa oikeudessa ilman, että heidän tarvitsee kohdata heitä hyväksikäyttäneitä rikollisia.

Lapset ihmiskauppiaiden uhreina ovat erittäin haavoittuvaisia. Lasten tunnistaminen ihmiskauppiaiden uhreiksi on ollut vaikeaa. Monet lapset katoavat, eivätkä viranomaiset tiedä, minne he ovat joutuneet. Syksyllä 2015 suuren pakolaisaallon mukana Pohjoismaihin tuli monia lapsia yksin tai yhdessä sellaisten aikuisten kanssa, jotka eivät olleet lapsen sukulaisia. Lapset eivät kerro siitä, että heitä on käytetty hyväksi. Aikuiset, joiden kanssa he matkustavat, saattavat olla ainoita 
aikuisia heidän elämässään, minkä vuoksi lapset eivät uskalla kertoa tulleensa hyväksikäytetyiksi.

Konferenssissa keskusteltiin myös siitä, miten ihmiskauppiaat kohtelevat naisia ja miehiä. Useimmat prostituutiota ja seksuaalista hyväksikäyttöä varten tapahtuvan ihmiskaupan uhreista Euroopassa ovat nykyään naisia, heidän osuutensa kaikista tunnistetuista uhreista on $69 \%$. Miehiä käytetään eri tavoin hyväksi pakkotyössä, ja miehet kokevat itsensä harvoin ihmiskaupan uhreiksi. Uhrien auttamisjärjestelmät on nykyään rakennettu useimmiten prostituutiossa seksuaalisesti hyväksikäytettyjen naisten tarpeiden pohjalta. Pohjoismaissa on nykyään enemmän ymmärrystä sille, että naiset ja miehet uhreina tarvitsevat erilaisia avun muotoja. Auttamisjärjestelmiä kehitetään siten, että niillä vastataan uhrien tarpeisiin sekä annetaan heille tukea ja apua, jotta he voivat luoda itselleen uuden elämän.

Paneelikeskustelun päätelmä oli se, että pohjoismaista yhteistyötä ihmiskaupan vastaisissa toimissa tarvitaan, jotta voidaan vaihtaa kokemuksia ja tietoa menetelmistä, joiden avulla voidaan torjua ihmiskaupan kaikkia muotoja. Yksittäisissä Pohjoismaissa ei ole nykyään niin monia ihmiskauppaan liittyviä oikeustapauksia. Tämän vuoksi on tärkeää, että ihmiskaupparikosten parissa työskentelevät poliisit, syyttäjät ja tuomarit voivat pohjoismaisissa konferensseissa vaihtaa kokemuksia ja keskustella ihmiskaupasta laajasta näkökulmasta kattaen kaiken rikollisten toiminnasta, poliisitutkinnasta ja oikeudenkäynneistä uhrien auttamisjärjestelmiin. Paneelissa painotettiin myös, että on tärkeää keskustella ihmiskaupasta julkisuudessa tiedon levittämiseksi, jotta ihmiset oppivat tunnistamaan ihmiskauppaa myös lähiympäristössään. 


\section{Summary}

The conference on The Nordic Countries - a Common Market for Human Trafficking took place on 26 October 2017 in Helsinki, Finland.

The challenges shared by the Nordic countries in fighting human trafficking were the subject of discussion during the conference. The aim was to exchange experiences on new trends in human trafficking; children as victims of human trafficking; legal processes, from the identification of the victims to decisions handed down by courts; and identification of and help for victims. A gender perspective was integrated into the conference program, and all speakers were given the task of reflecting in their presentations on how human trafficking affects women and men, and girls and boys.

In newer forms of human trafficking, women and men, and girls and boys are exploited by being forced to carry out criminal acts, work in certain sectors [which sectors?] and sell sexual services. Human traffickers lure individuals with promises of work and housing, inducing them to travel to the Nordic countries and other parts of Europe. The traffickers also use victims' identification documents for benefits fraud within the Nordic welfare systems. The victims are often not aware of being used in criminal actions.

One of the challenges in combating human trafficking in the Nordic countries presently is that traffickers regard the Nordic region as a common market and send victims from one country to another. This poses major challenges for criminal investigators, as legislation itself is national while the crimes transcend borders, as the same traffickers operate simultaneously in different Nordic countries. There is now a heightened need for cooperation between authorities and organisations in order to step up measures against human trafficking crimes.

The conference used as its starting point the various results and experiences obtained from joint-Nordic initiatives by the Nordic Council of Ministers and organizations throughout the Nordic countries. A wealth of knowledge in the form of national reports, analyses, recommendations and measures for combating human trafficking is available for use.

The conference discussions focused on three themes:

1. Children as victims of human trafficking

2. Challenges in the legal process

3. Women and men as victims of human trafficking

The conference concluded with a panel discussion titled How can the Nordic countries cooperate on actions against human trafficking?

The conference discussions also addressed the following issues: 
- What new forms of human trafficking are occurring in the Nordic countries and Europe?

- What challenges do police and prosecutors face today in investigating different forms of human trafficking?

- How are child victims of human trafficking exploited and how are the cases investigated (handled)?

- How are women and men exploited differently as victims of human trafficking?

- Why is human trafficking for sexual exploitation a gender equality issue?

- What methods do perpetrators use to gain power over their victims?

- Which are the psychological consequences of human trafficking?

- What are the best ways to exchange experiences, working methods and knowledge?

- What are the best practical ways to cooperate in border-crossing investigations?

- What can be achieved within the framework of Nordic cooperation?

The conference gathered 160 participants from all of the Nordic countries. In total, 43 $\%$ of participants were representatives of police and the judiciary; of them, 37 were police officers and 32 were prosecutors, judges and attorneys. Other participants included civil servants, various experts, researchers and representatives of non-governmental organisations.

The conference was organized by the Non-Discrimination Ombudsman in Finland - also the National Rapporteur for Trafficking in Human Beings for Finland - in cooperation with the Finnish chairmanship of the Nordic Council of Ministers. The conference was financed by the Council of Ministers for Gender Equality (MR-JÄM), Council of Ministers for Legislative Affairs (MR-LAG) and the Nordic Committee for Children and Young People (NORDBUK).

The conference presentations from The Nordic Countries - a Common Market for Human Trafficking are available at:

- $\quad$ https://www.syrjinta.fi/sv/web/sv/-/nordisk-konferens-norden-som-gemensam-

marknad-for-manniskohandel 
Pohjoismaiden ministerineuvosto

Nordens Hus

Ved Stranden 18

DK-1061 København K

www.norden.org

\section{Pohjoismaat ihmiskaupan markkina-alueena}

Ihmiskaupan uusissa muodoissa käytetään hyväksi naisia ja miehiä, tyttöjä ja poikia pakottamalla heidät rikolliseen toimintaan, työhön ja myymään seksipalveluja. Ihmiskauppiaat käyttävät hyväkseen pohjoismaiden hyvinvointijärjestelmää ja uhrien identiteettejä hankkimalla itselleen $\mathrm{mm}$. sosiaalietuuksia.

Yksi ihmiskaupan torjunnan haasteista pohjoismaissa on, että ihmiskauppiaat katsovat pohjoismaat yhdeksi markkinaalveeksi. Tämä muodostaa rikostutkijoille suuria haasteita, sillä lainsäädäntö on kansallista ja rikokset rajat ylittäviä ja ihmiskauppiaat toimivat samaan aikaan Pohjolan eri maissa. Konferenssi osoitti, että tarvitaan enemmän yhteistyötä ihmiskaupan vastaisten toimien ja rikostorjunnan tehostamiseksi.

Konferenssissa Pohjoismaat ihmiskaupan markkina-alveena keskusteltiin lapsista, naisista ja miehistä ihmiskaupan uhreina ja rikosprosessin haasteista. 